\title{
O GÊNERO Copaifera L.
}

Valdir F. Veiga Junior e Angelo C. Pinto*

Instituto de Química, Universidade Federal do Rio de Janeiro, CT, Cidade Universitária, Ilha do Fundão, 21945-970 Rio de Janeiro - RJ

Recebido em 12/12/00; aceito em 4/7/01

THE Copaifera L. GENUS. This review details the history, chemistry and pharmacology of the Copaifera L. genus (Leguminosae - Caesalpinoideae), including copaiba oils.

Keywords: Copaifera; copaiba oil; diterpenes.

\section{INTRODUÇÃO}

Os trabalhos realizados sobre o gênero Copaifera L. estão, em sua maioria, relacionados com o óleo que é exudado do tronco destas árvores, o óleo de copaíba, facilmente encontrado na região tropical da América Latina. Desde os primeiros anos do descobrimento do Brasil, o óleo de copaíba vem sendo indicado para diversos fins, farmacológicos ou não.

Por sua ampla utilização, muitos estudos foram realizados sobre este gênero, abordando suas diversas aplicações. Apesar dos mais de 200 trabalhos publicados em diversas línguas, muitos dados sobre a composição química e atividade farmacológica do óleo de copaíba são contraditórios. Há equívocos desde a identificação botânica até a composição química dos óleos de copaíba, que são também frequientemente misturados a outros óleos e adulterados.

É, portanto, objetivo deste trabalho realizar uma revisão sobre o gênero Copaifera L., abordando sua história, química e farmacologia.

\section{CLASSIFICAÇÃ̃O BOTÂNICA, DISTRIBUIÇÃO DO GÊNERO Copaifera E O ÓLEO DE COPAÍBA}

A nomenclatura botânica segue, como norma, os nomes mais antigos dados às plantas. Em alguns casos, entretanto, são feitas exceções frente à utilização corrente de outros nomes. Uma destas exceções está nas leguminosas, cujo nome mais antigo é Faba, mas Fabaceae Lindley dá lugar a Leguminosae Juss., na nomenclatura desta que é uma das mais importantes famílias botânicas. A classificação mais moderna da família Leguminosae a divide em três subfamílias: Caesalpinoideae, Mimosoideae e Papilionoideae (ou Faboideae $)^{1}$. Por esta classificação, que segue o sistema de Engler, o gênero Copaifera L. pertence à família Leguminosae Juss., sub-família Caesalpinoideae Kunth. Segundo outro sistema de classificação, o de Cronquist, o gênero Copaifera L. pertence à família Caesalpiniaceae R.Br. A classificação apenas como Fabaceae também é encontrada em alguns livros ${ }^{2,3}$.

Muitos botânicos e cronistas que estiveram nas Índias Ocidentais e na América no início da colonização descreveram espécies do gênero Copaifera. Em 1628, MarcGrave e Piso descreveram os aspectos morfológicos da planta, empregando o termo "Copaiba" sem designar espécies ${ }^{4}$. Mais tarde verificou-se, através dos caracteres

\footnotetext{
*e-mail: angelo@iq.ufrj.br
}

descritos pelos dois cronistas, que a espécie estudada foi a Copaifera martii $^{5}$. Em 1760, Jacquin ${ }^{6}$ descreveu em detalhes a primeira Copaifera como Copaiva officinalis Jacq. mas, como não possuía o fruto, baseou sua descrição nos aspectos do fruto da espécie estudada por MarcGrave e Piso. Somente dois anos depois, o cientista sueco Carl von Linneu descreveu corretamente a Copaifera officinalis ${ }^{7}$, assumindo a descrição oficial do gênero Copaifera L.

Em 1825, Hayne ${ }^{8}$ publicou uma monografia com oito novas espécies de Copaifera que, apesar de um pouco confusa em vista do conhecimento atual, constituiu o mais importante tratado de descrição do gênero e serviu como base para estudos como o de Bentham, no Flora Brasiliensis, realizado durante a expedição com o naturalista von Martius ${ }^{9}$, em 1870.

Os trabalhos mais recentes de descrição de novas espécies foram os realizados por Harms e Ducke, este último com contribuições de extremo valor sobre as espécies da Região Amazônica ${ }^{10,11}$ e do estado do Ceará ${ }^{12}$, e por Dwyer, que realizou um levantamento das espécies americanas ${ }^{13,14}$.

As copaíbas são árvores nativas da região tropical da América Latina e também da África Ocidental. Na América Latina são encontradas espécies na região que se estende do México ao norte da Argentina $^{5,9,14-16}$.

Segundo a última edição do Index Kewensis ${ }^{17}$, o gênero Copaifera possui 72 espécies, sendo que dezesseis destas só são encontradas no Brasil $1^{5}$.

Popularmente conhecidas como copaibeiras ou pau d'óleo, as copaíbas são encontradas facilmente nas Regiões Amazônica e Centro-oeste do Brasil. Entre as espécies mais abundantes, destacam-se: C. officinalis L. (norte do Amazonas, Roraima, Colombia, Venezuela e San Salvador $)^{18}$, C. guianensis Desf. (Guianas), C. reticulata Ducke, C. multijuga Hayne (Amazônia), C. confertiflora Bth (Piauí), $C$. langsdorffii Desf. (Brasil, Argentina e Paraguay), C. coriacea Mart. (Bahia), C. cearensis Huber ex Ducke (Ceará) ${ }^{19-23}$.

No Brasil, a espécie $C$. langsdorfii Desf. é particularmente importante por estar distribuída por todo o território (da Amazônia a Santa Catarina, no nordeste e centro-oeste) e por possuir quatro diferentes variedades: $C$. langsdorfii var. grandifolia, grandiflora, laxa e glabra $^{24}$.

Na África Ocidental são descritas 19 espécies na região que inclui Congo, Camarões, Guiné e Angola. Destas, as espécies $C$. convertifolia, C. demeusii (Copal do Congo) ${ }^{25}$, C. coleosperma (Copal da Rodésia) ${ }^{26}, C$. conjugata, $C$. hymenaefolia, $C$. chodatiana e $C$. fissicuspis ${ }^{27}$, descritas como pertencentes ao gênero Copaifera, têm sinonímia nos gêneros Guibourtia ${ }^{28}$, Gorakia (Gorakia conjugata) ${ }^{28}$ 
e Cynometra $(\text { C } \text {. fissicuspis })^{5,13,29}$. Nesta região são comuns as citações de âmbares (óleo-resinas fossilizadas) provenientes de espécies do gênero Copaifera ${ }^{25,26}$.

Há, ainda, a citação de uma espécie encontrada na Ilha de Bornéo, Malásia, chamada de Copaifera palustris, que apresenta caracteres bastante semelhantes aos das espécies africanas e ao gênero Pseudosindora ${ }^{30}$.

A Figura 1 mostra o mapeamento das regiões onde espécies do gênero Copaifera foram encontradas.

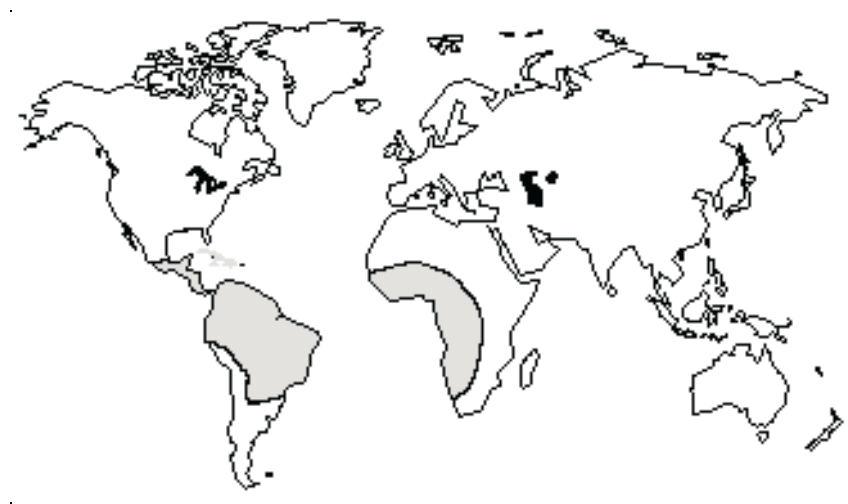

Figura 1. Regiões onde o gênero Copaifera é encontrado

As copaibeiras são árvores de crescimento lento, alcançam de 25 a 40 metros de altura, podendo viver até 400 anos. O tronco é áspero, de coloração escura, medindo de 0,4 a 4 metros de diâmetro. As folhas são alternadas, pecioladas e penuladas. Os frutos contêm uma semente ovóide envolvida por um arilo abundante e colorido. As flores são pequenas, apétalas, hermafroditas e arranjadas em panículos axilares $^{6,15,21,31,32,33}$

A floração e frutificação das copaíbas ocorrem a partir dos 5 anos de idade, em plantios. A floração ocorre entre outubro e julho e a frutificação entre junho e outubro, com variações dentro destes intervalos, dependendo da região e clima, com ausência de florescimento anual, em algumas regiões ${ }^{34,35}$.

Nectíferas, algumas espécies, como a Copaifera langsdorfii, são polinizadas no período diurno, de 8:00 às 16:00 horas, com grande participação de Trigona $s p$ e Apis mellifera ${ }^{36}$, tendo sido encontrados grãos de pólen provenientes de Copaifera em amostras de mel do estado do Ceará ${ }^{37}$.

À época da frutificação, as copaíbas são visitadas no período diurno por aves, as quais são as maiores responsáveis pela dispersão de suas sementes, como o tucanuçu (Ramphastos toco), a galha-docampo (Cyanocorax cristatellus) e o sabiá, que engolem o arilo e regorgitam a semente ${ }^{34}$. No período noturno, as copaíbas são ponto de encontro de diversos mamíferos, como os macacos mono-carvoeiros (Cebus apella nigritus) ${ }^{38}$, observados no Parque Nacional de Iguazu, na Argentina, e que utilizam sua copa como ponto de descanso noturno, como pequenos roedores que apreciam os frutos e são atraídos pelo cheiro de cumarina presente nas sementes maduras e, por último, os silvícolas, no norte do país, que apreciam a carne destes pequenos roedores e utilizam as copaíbas como local de espera de caça.

A biologia das sementes de $C$. langsdorfii foi estudada por diversos pesquisadores que abordaram desde sua morfologia e anatomia ${ }^{39}$, passando pela sua conservação ${ }^{40}$ e maturação ${ }^{41}$, até a germinação ${ }^{42}$.

Sua identificação botânica é difícil, sendo realizada, na maioria das vezes, segundo características das flores, como: pubenescência das sépalas, comprimento dos anteros e a condição glaborosa ou não do pistilo ${ }^{5}$. As características dos frutos são igualmente importantes, mas estes são dificilmente encontrados em coleções botânicas.

A designação correta para o óleo da copaíba é a de óleo-resina, por ser um exudato constituído por ácidos resinosos e compostos voláteis ${ }^{43}$. Também é chamado, erroneamente, de bálsamo de copaíba $^{44,45}$, apesar de não ser um bálsamo verdadeiro, por não conter derivados do ácido benzóico ou cinâmico ${ }^{5,21,46}$.

O óleo de copaíba é encontrado em canais secretores localizados em todas as partes da árvore. Estes canais são formados pela dilatação de espaços intercelulares (meatos) que se intercomunicam no meristema, chamados de canais esquizógenos ${ }^{47}$. O caráter mais saliente deste aparelho secretor está no tronco, onde os canais longitudinais, distribuídos em faixas concêntricas, nas camadas de crescimento demarcadas pelo parênquima terminal, reúnem-se com um traçado irregular, em camadas lenhosas, muitas vezes sem se comunica$\mathrm{rem}^{15,47}$. Segundo alguns autores, o óleo é produto da desintoxicação do organismo vegetal e funciona como defesa da planta contra animais, fungos e bactérias ${ }^{15}$.

São vários os métodos relatados para a retirada do óleo de copaíba. Antigamente, obtinha-se o óleo através de cortes a machado no tronco, o que inutilizava a árvore ${ }^{48}$. A incisão em V, colocando-se abaixo vasos apropriados para receber o óleo, à semelhança da extração de borracha ${ }^{47,49}$, e o chamado método do arrocho, que consiste em selar o tronco, abaixo das incisões, com embiras e cipós e coletar o óleo da árvore até o seu esgotamento, provocando sua morte, são métodos há muito tempo abandonados ${ }^{47}$. A retirada por meio de bomba de sucção também é descrita ${ }^{50}$, porém pouco difundida.

A única prática de coleta não agressiva é aquela realizada através de uma incisão com trado a cerca de 1 metro de altura do tronco $^{15,51}$. Terminada a coleta, o orifício é vedado com argila para impedir a infestação da árvore por fungos ou cupins. A argila pode ser facilmente retirada, permitindo que se façam outras coletas no mesmo tronco $0^{52}$, obtendo-se quantidade de óleo igual ou mesmo superior a da primeira retirada ${ }^{15}$. Nesta primeira extração a quantidade de óleo obtido varia bastante. Alguns cronistas descreveram que uma única árvore pode gerar até 40 ou 50 litros de óleo por $\mathrm{ano}^{4,49,53}$, apesar de nem todas as espécies serem capazes de produzir essa quantidade $^{21}$.

O interesse na madeira de determinadas espécies de Copaifera também é grande. Sua superfície é lisa, lustrosa, durável, de alta resistência a ataque de xilófagos e baixa permeabilidade, própria para fabricação de peças torneadas e de marcenaria em geral ${ }^{54}$. A árvore também é utilizada na fabricação de carvão ${ }^{55}$ e pelas indústrias de construção civil e naval ${ }^{22,34}$.

O interesse pela madeira e a utilidade do óleo de copaíba fez com que o governo imperial regulasse a derrubada das copaibeiras através de um ato expedido em 1818, segundo o qual as árvores só poderiam ser derrubadas por conta do estado, vendidas com $20 \%$ de lucro para a produção de mastros e vergas de navio ${ }^{56}$.

Apesar deste ato, as árvores continuaram a ser derrubadas até os dias atuais, com a sua extração não racional. $\mathrm{O}$ interesse na madeira e os desmatamentos crescentes na Região Amazônica acabaram transformando o óleo de copaíba em subproduto da indústria madeireira. Sua fonte nos mercados municipais de Manaus e Belém, varia de acordo com a situação das estradas que levam os caminhões com madeira por toda parte. No estado de Rondônia é comum encontrar mulheres e filhos de madeireiros ao longo da estrada que liga Porto Velho a Ariquemes e Ji-Paraná, vendendo óleo de copaíba em baldes de plástico. Hoje em dia, a maior parte do óleo é obtido através do processo de extração total, com a derrubada da árvore.

O óleo de copaíba é um líquido transparente cuja coloração varia do amarelo ao marrom. Para a utilização farmacológica os óleos 
mais escuros e viscosos ${ }^{57}$ são os preferidos ${ }^{49,50,58-62}$. Somente na espécie $C$. langsdorfii o óleo de copaíba apresenta-se vermelho, semelhante ao sangue de dragão (Croton $s p$.), recebendo a denominação popular de copaíba vermelha ${ }^{63,64}$.

Segundo Lawrence ${ }^{65}$, as espécies botânicas mais freqüentemente utilizadas na produção de óleo são: C. reticulata $(70 \%)$, C. guianensis (10\%), C. multijuga (5\%) e C. officinalis (5\%).

Dentro de determinada espécie produtora também ocorrem variações quali e quantitativas ${ }^{66}$. Algumas árvores praticamente não exudam óleo ou o fazem em quantidades muito pequenas para coleta (o que os mateiros chamam de "árvores macho") ${ }^{67}$. A quantidade de resina pode ser influenciada (aumentada) por fatores como o aumento de luminosidade e a diminuição de nitrogênio no solo ${ }^{68}$. Nos estudos realizados com $C$. multijuga, com retiradas periódicas de óleo de copaíba, foram obtidas maiores quantidades de óleo na estação chuvosa em árvores localizadas em terreno argiloso ${ }^{15}$.

Um dos aspectos interessantes da copaíba é o procedimento da retirada do óleo utilizado pelos indígenas e ainda observado no interior do Brasil. Muitos destes procedimentos são considerados místicos pela ciência de hoje, embora tenham sido adquiridos pelos indígenas através da experimentação empírica durante milhares de anos. Vários cronistas, que estiveram na América Latina em regiões tão diferentes como a bacia amazônica e do Prata e o nordeste brasileiro, relatam a utilização das mesmas técnicas por índios separados por milhares de quilômetros.

Segundo o Príncipe Maximiliano ${ }^{69}$, que esteve na região do Espírito Santo no início do século XIX, “...é crença geral que a incisão deva ser feita em lua cheia e o óleo colhido no quarto minguante...”. João Ferreira Rosa, em seu Tratado Único da Constituição Pestilencial ${ }^{70}$, de 1694, relatava: "Neste pau, nas noites de lua cheia, quando os frutos estão maduros, se faz golpe até a medula,..., correr óleo em grande quantidade.".

Ainda hoje os mesmos procedimentos são seguidos pelos silvícolas, alguns deles, com muito misticismo. Afirmam que quando o machado atinge o cerne, a árvore dá um longo suspiro e o óleo começa a correr ${ }^{56}$. Para a retirada do óleo, segundo estes, a árvore não deve ser olhada diretamente (para a copa), sob pena da árvore secar e o óleo voltar para a terra. A ascendência do óleo da terra é comumente relatada por mateiros do norte do país, embora não encontrada na literatura. Segundo alguns deles, sob a influência da lua cheia de agosto, o óleo sobe da terra para a árvore e esta é a época mais indicada para a retirada do óleo. Vários relatos confirmam este período de coleta ${ }^{53,70,71}$.

\section{HISTÓRICO E APLICAÇÕES DO ÓLEO DE COPAÍBA}

A origem do nome copaíba parece vir do tupi cupa-yba, a árvore de depósito, ou que tem jazida, em alusão clara ao óleo que guarda em seu interior ${ }^{72}$. Chamado de copaíva ${ }^{73}$ ou copahu $^{74}$ pelos indígenas (do tupi: Kupa'iwa ${ }^{74}$ e Kupa' $\dot{\mathrm{u}}^{75}$, respectivamente), e cupay, na Argentina e no Paraguai (guarani) ${ }^{76}$, o óleo de copaíba e suas propriedades medicinais eram bastante difundidos entre os índios latinoamericanos à época que aqui chegaram os primeiros exploradores europeus no século XVI. Este conhecimento, tudo indica, veio da observação do comportamento de certos animais que, quando feridos, esfregavam-se nos troncos das copaibeiras para cicatrizarem suas feridas $^{77,78}$, como observou o holandês Gaspar Barléu ${ }^{78,79}$ :

\section{“...Vêem-se estas plantas esfoladas pelo atrito dos animais, que, procuram instintivamente este remédio da natureza...”}

As propriedades do óleo tão apreciado pelos índios, que o usavam principalmente como cicatrizante e antiinflamatório, fizeram com que a copaíba fosse uma das primeiras espécies a serem descritas pelos cronistas portugueses ${ }^{80-82}$.

A primeira citação sobre o óleo talvez tenha sido em uma carta de Petrus Martius ao Papa Leão X, publicada em Estrasburgo em 1534, em que a droga utilizada pelos índios era chamada de "Copei"'.

Uma publicação da mesma época do padre Jesuíta José Acosta, "De Natura Novi Orbis", foi traduzida do latim para o francês em 1606. Na tradução portuguesa de José Maffeu, intitulada "História Natural e Moral das Índias", encontra-se o seguinte trecho ${ }^{83}$ :

\section{“... o bálsamo é celebrado com razão por seu excelente odor, e muito maior efeito para curar feridas, e outros diversos remédios para enfermidades, que nele se experimentam... ...nos tempos antigos os índios apreciavam em muito o bál- samo, com ele os índios curavam suas feridas e que delas aprenderão os espanhóis..."}

O jesuíta José de Anchieta, em sua longa carta ao Padre Geral, datada de São Vicente, em fins de 1560, comenta as utilidades do óleo de copaíba ${ }^{84}$ :

\section{“...exala um cheiro muito forte porém suavíssimo e é ótimo para curar feridas, de tal maneira que em pouco tempo nem mesmo sinal fica das cicatrizes."}

A descoberta da terapêutica indígena permitiu que os primeiros médicos que trabalharam no Brasil contornassem parcialmente a escassez dos remédios empregados na Europa, cujo suprimento à Colônia era intermitente. As práticas indígenas eram tão difundidas, que os viajantes sempre se abasteciam destes medicamentos, "comprovadamente eficientes", antes de excursões por regiões pouco conhecidas ${ }^{82}$.

As utilidades farmacológicas do óleo de copaíba também foram citadas em 1576, por Pero Magalhães Gandavo, um dos primeiros cronistas da História Brasileira ${ }^{67,85}$.

As citações mais remotas da aceitação desta farmacopéia indígena na América pelos europeus datam de 1587, quando Gabriel Soares de Sousa (c.1540-c.1592), no seu "Tratado Descritivo do Brasil", registrou a utilização do óleo de copaíba e chamou os produtos medicinais utilizados pelos índios de "as árvores e ervas da virtude" 82 .

Todos os mais importantes cronistas que estiveram no Brasil relataram as propriedades dos óleos de copaíba. Ainda no século XVI, Jean de Lery ${ }^{74}$, em 1578, e os padres Fernão Cardim ${ }^{77}$, em 1584, Francisco Soares ${ }^{86}$, em 1594 e Simão Travaços ${ }^{87}$, em 1596, citam o óleo como um excelente cicatrizante.

No século XVII, vários outros viajantes relatam as propriedades deste óleo, como Rodrigues ${ }^{88}$, em 1607, Silveira ${ }^{89}$, em 1624, e Morão ${ }^{90}$, em 1677, ano em que o óleo de copaíba foi inserido na farmacopéia britânica ${ }^{19}$.

São muitas as denominações que o óleo das copaibeiras recebe nas diversas regiões da América Latina onde é utilizado. Na Região Amazônica o uso do óleo de copaíba é tão extenso, que a copaíba destaca-se como a planta medicinal mais utilizada e conhecida pela população ${ }^{91}$. O óleo pode ser encontrado em mercados populares e é conhecido por diferentes denominações, como: Copahyba, Copaibarana $^{61}$, Copaúba, Copaibo, Copal, Maram, Marimari e Bálsamo dos Jesuítas ${ }^{57}$.

Fora da Região Amazônica a espécie mais comum é a Copaifera langsdorfii, conhecida por diversos nomes nas várias regiões onde é encontrada, a saber: óleo-de-copaíba (RJ, SP, ES), óleo-pardo, óleovermelho (BA, RJ, SP), bálsamo, caobi, capaíba, capaúba (MS), coopaíba (MG), copaí, copaibeira, copaibeira-de-minas, copaúba (SP), copaíba-preta, copaíba-de-várzea, copaíba-vermelha, óleo- 
amarelo, óleo-capaíba (BA, MG), copaúva, cupaúva, cupiúva, cupiuba, oleiro, óleo (MG, PR), pau-óleo (PR), pau-óleo-de-copaíba, pau-óleo-do-sertão (BA), pau-d'óleo, podoi (PI, CE), e copaibeira nos demais estados do sul do país ${ }^{92}$.

$\mathrm{Na}$ Venezuela o óleo de copaíba é o aceite de palo, cabimba, cabima, aceite de zaraza ou balsamo de copaiba e na França, o huile de copahu, baume de copahu ou huile rouge de copayer ${ }^{33}$.

A confusão de nomes é bastante grande mesmo dentro de um só estado. A Copaifera martii, por exemplo, é conhecida no Pará como copaíba ou copaíba jutaí, em Óbidos, jutaí pororoca, em Montalegre e copaibarana, em Santarém ${ }^{93}$. Jutaí e copaibarana também são nomes populares de outras duas leguminosas: Hymenea courbaril e Macrolobium microcalix ${ }^{32}$, respectivamente. Copaibuçu (ou, copaíba grande) é um nome atribuído a Ficus gameleira (Moraceae) ${ }^{94}$, pela semelhança da copa das duas árvores quando encontradas em regiões abertas ${ }^{95}$.

Não só os nomes mas também os óleos de copaibeiras são confundidos com óleos de árvores de outros gêneros da família Leguminosae. A confusão mais comum ocorre com os óleos do gênero Eperua. Apesar de mais resinosos e de coloração diferente, esverdeados, os óleos exudados das espécies E. oleifera e E. purpurea são conhecidos popularmente com nomes correlatos aos da copaíba, como copaíba-jacaré ${ }^{20}$ e copaibarana, respectivamente ${ }^{11}$. O óleo da espécie E. falcata ${ }^{96}$ também é utilizado na medicina popular de modo análogo ao da copaíba ${ }^{97}$, como cicatrizante, antifúngico e bactericida ${ }^{96}$.

As utilizações da medicina popular para o óleo de copaíba são muitas ${ }^{15,21,44,98-102}$ e indicam uma grande variedade de propriedades farmacológicas. As principais atividades relatadas foram de antiinflamatório das vias superiores e inferiores e cicatrizante. A Tabela 1, abaixo, apresenta algumas das utilizações populares dos óleos de copaíba.

Devido ao grande número de indicações medicinais, o óleo de copaíba já foi considerado a verdadeira panacéia ${ }^{70}$, mas a sua utilização e, principalmente, sua prescrição médica diminuíram muito nas últimas décadas. À época do seu descobrimento pela terapêutica ocidental, algumas de suas principais propriedades foram deixadas de lado em função de sua grande atividade contra alguns males para os quais não havia medicação eficiente, como a blenorragia e a gonorréia. No século XVIII, a experiência secular já então limitava as indicações e o produto fez-se quase um específico para as vias urinárias. Assim o empregaram F. Hoffmann (1660-1742), W. Cullen (17101790) e J. Hunter (1748-1793) e Trousseau (1801-1867) ${ }^{70}$.

A descoberta neste século de agentes terapêuticos sintéticos mais eficientes, como a penicilina ${ }^{106}$, diminuiu bastante sua utilização.

Para outras indicações, como as propriedades cicatrizantes, para o qual o óleo de copaíba foi muitas vezes descrito, é pequena a utilização nos dias de hoje. Nos últimos anos, entretanto, o retorno à terapêutica natural trouxe de volta os fitoterápicos para as farmácias de todo o país, mas o conhecimento de sua utilização e suas aplicações se perderam, ou aparecem bastante confusos nas centenas de publicações que não apresentam mais que duas ou três propriedades farmacológicas já bastante conhecidas.

Algumas das propriedades hoje esquecidas são descritas por pesquisadores que estudaram sua utilização junto aos silvícolas. Um exemplo é a descrição de Bertoni ${ }^{105}$, que passou vários anos estudando os costumes dos índios guaranis no Paraguai:

"É evidente a ação do óleo de copaíba C. langsdorfii, no tratamento do reumatismo! Utiliza-se nas desinterias, em casos mais graves, onde a ipeca não resolvia. Em especial nos casos mais graves, com retite gangrenosa. (...) Era a essa resina que apelavam quando não queriam que as feridas deixassem nenhuma cicatriz."
Convivendo com os tapuias, $\operatorname{Rosa}^{70}$ foi um dos cronistas que melhor descreveu as utilizações do óleo de copaíba e a forma como deveria ser aplicado. As aplicações a quente e em compressas em partes externas só são encontradas em relatos mais antigos e hoje abandonadas da terapêutica. Rosa cita ainda a utilização do óleo em massagens na cabeça para curar paralisias, dores de cabeça e convulsões.

O chá das cascas e sementes da Copaifera também é indicado para diversos males, especialmente na Venezuela e Colômbia, onde são utilizados como anti-hemorroidal e purgativo ${ }^{115,116,122}$ e na Amazônia Brasileira é indicado no tratamento de moléstias pulmonares e asma $^{34}$.

$\mathrm{Na}$ África Ocidental (Camarões) encontra-se apenas uma utilização medicinal para um óleo de copaíba específico, Copaifera religiosa, indicado no tratamento da sífilis e blenorragia ${ }^{123}$.

Tabela 1. Indicações etnofarmacológicas dos óleo de copaíba encontradas na literatura

\begin{tabular}{lc}
\hline Propriedade farmacológica & Referência \\
\hline Vias urinárias & \\
Anti-blenorrágico & $43,47,56,73,92,93,104,114,115$ \\
Anti-inflamatório & 118,119 \\
Anti-gonorréico & $47,58,106,116$ \\
Antisséptico & $43,47,106$ \\
Cistite & $19,43,56,109,114$ \\
Estimulante & $19,53,73,104$ \\
Incontinência urinária & 60,103 \\
Sífilis & 3,60
\end{tabular}

Vias respiratórias

Anti-asmático

122

Bronquite

Espectorante

Inflamações de garganta

(em embrocações)

Hemoptise

Pneumonia

Sinusite

$19,43,56,60,103,114,122$

47

$118,119,121$

118

120

118

Males da pele

103

Dermatite

3

Eczema

Psoríase

$31,56,108,109,110$

\section{Cicatrizante de feridas e ulceras e intra-uterino}

$3,19,56,58,61,92,93$, $111,114,116,118,119,120$

\section{Outros}

Afrodisíaco

Anti-tetânico (principalmente em

recém-nascidos)

Anti-tetânico (contra o bacilo do

tétano e nas convulsões)

Anti-reumático

Anti-herpético

Anti-cancerígeno

Anti-tumoral (tumores de próstata)

Leishmaniose

Leucorréia

Contra paralisia

$56,93,114,117$

$58,60,119$

Dores de cabeça

Picada de cobra

$92,105,115,120$

119

61,121

113

96

56, 103

120

120

70,79 
Em artigo recente, Fleury reviu as utilizações medicinais do óleo de copaíba na região da Guiana Francesa, onde é utilizado contra psoríase, leishmaniose e como cicatrizante e antiinflamatório ${ }^{97}$.

A disseminação da indústria de produtos naturais em todo mundo e no Brasil, nos últimos anos, levou à comercialização extensiva do óleo de copaíba pelos laboratórios farmacêuticos. Das pequenas cidades do interior da Amazônia, os óleos de copaíba são transportados para as cidades de Manaus e Belém, de onde são exportados para a Europa e América do Norte ou enviados para a região sudeste para serem vendidos pelas farmácias que comercializam produtos naturais. Os óleos podem ser encontrados nas farmácias de todo o país em diversas apresentações. As mais comuns são em cápsulas ou envasados em pequenos frascos de $30 \mathrm{ml}$.

No norte do Brasil, o caboclo faz amplo uso do óleo de copaíba. Ele o utiliza como produto medicinal e também como combustível na iluminação pública. As grandes distâncias, que devem ser vencidas na selva para encontrar as copaíbas, em geral 0,2-0,3 árvores por hectare, fazem com que a mistura do óleo de copaíba com outros óleos tornese prática comum. Os mateiros muitas vezes armazenam no mesmo recipiente os óleos de todas as copaibeiras que encontram, sem se preocuparem se provêm de árvores da mesma espécie botânica. Também os misturam com bálsamo de gurjum e com óleos de espécies de Calophyllum, que possuem densidade e aroma semelhantes ${ }^{99}$.

É comum também a adulteração do óleo de copaíba com produtos de menor valor agregado, com o objetivo de diluir o óleo. Estas adulterações já eram descritas desde o começo do século tanto na Europa, onde o óleo, exportado, era misturado com óleo de madeira e colofane ${ }^{21}$, como no Brasil, onde publicações alemãs ensinavam como e onde comprar óleos de boa qualidade em cidades da Amazônia $^{99,124}$. Hoje em dia ainda é comum que intermediários na comercialização do óleo de copaíba o misturem com água, óleo diesel e banha animal ${ }^{125}$. Essas adulterações devem ainda ser somadas àquelas praticadas pelos laboratórios farmacêuticos, que utilizam óleos vegetais comestíveis como a soja e o milho para a diluição. Só recentemente uma metodologia para detectar estas adulterações foi desenvolvida ${ }^{126}$

A exportação dos óleos de copaíba para a Europa foi registrada desde o final do século XVIII, ocupando o segundo lugar nas exportações brasileiras de drogas medicinais ${ }^{127,128}$. Naquela época era comum que comunidades indígenas inteiras, da grande área que se estende desde a Região Amazônica até os estados de Maranhão e Mato Grosso, se ocupassem da extração do óleo ${ }^{82}$.

Os franceses foram os que mais se dedicaram ao estudo e exploração do óleo de copaíba no passado. No período que antecedeu a primeira grande guerra, Hamburgo, na Alemanha, era o principal centro de importação do óleo de copaíba do Brasil e o distribuía para a Europa (cerca de 50 ton./ano), sendo a França responsável pelo consumo de mais de 6 ton./ano ${ }^{52}$. No período de pós-guerra, entretanto, foi quando se alcançou os maiores valores globais de exportação do óleo, obtendo-se o máximo de 225 toneladas, no ano de $1918^{93}$.

Com os dados que dispomos, nos períodos de 1796 a 1807, de 1839 a $1870^{82}$, de 1901 a $1934^{93}$ e de 1962 a $1996^{129-131}$, podemos observar que as grandes oscilações na quantidade de óleo exportada continua até os nossos dias, com o volume variando de 101 a 59 toneladas de óleo nos anos de 1994 e 1996, respectivamente. Essa oscilação e a pequena quantidade de óleo de copaíba consumida no mercado interno dificultam a organização de cooperativas extrativistas nos estados do norte do país e, conseqüentemente, a sobrevivência das comunidades que têm na exploração do óleo sua fonte de subsistência.

Outros períodos de grande volume de exportação foram nos anos de 1925 e $1953^{82}$. A Figura 2 ilustra as variações no volume de exportações do Brasil de óleo de copaíba.

Nas últimas três décadas, o destino das exportações brasileiras de óleo de copaíba esteve dividido entre a França, a Alemanha, a Inglaterra e os Estados Unidos, este último o principal importador, alcançando 20,8 toneladas no ano de $1973^{129}$. Os últimos dados disponíveis datam de 1996. A partir de 1997, o óleo de copaíba, por apresentar pequeno volume no montante de produtos exportados, deixou de possuir estatística própria e passou a constar no volume de produtos minoritários dos anuários do IBGE. Segundo estes últimos dados, a Alemanha foi o país que mais importou o óleo de copaíba, superando Estados Unidos e França. A Figura 3 ilustra os principais importadores de óleo de copaíba e sua participação no volume total exportado entre 1962 e 1988, e em $1996^{129}$.

Na indústria de perfumes o óleo de copaíba é uma matéria-prima importante por ser um excelente fixador, com notas frescas e acres que combinam muito bem com as tradicionais notas florais ${ }^{132}$.

O óleo de copaíba é utilizado também nas indústrias de cosméti$\cos ^{97}$, por suas propriedades emolientes, como bactericida e antiinflamatório, na manufatura de sabonetes, cremes e espumas de banho, xampus ${ }^{133}$, cremes condicionadores ${ }^{134}$ loções hidratantes ${ }^{135} \mathrm{e}$ capilares, para amaciar o cabelo ${ }^{22}$.

$\mathrm{Na}$ indústria de vernizes ${ }^{132}$, o óleo de copaíba é utilizado na formulação como secativo ${ }^{136}$, substituindo o óleo de linhaça. Na pintura com porcelana, o óleo atua como solvente para as tintas em pó mas como seca rapidamente ( 2 a 3 dias) deve ser utilizado em conjunto com outros óleos para que a pintura demore mais para secar ${ }^{136}$. Já na pintura em tela, o óleo é utilizado como "amolecedor" de vernizes de pinturas antigas, procedimento que pode gerar diluição também da camada de tinta, prejudicando a pintura ${ }^{56,137}$. A utilização do óleo de copaíba na indústria de fotografia, como acelerador ${ }^{21}$, também é citada na literatura.

Os óleos de copaíba, por serem muito ricos em hidrocarbonetos isoprenóides, podem ser convertidos, na presença de zeólitas, em

Ton./ano

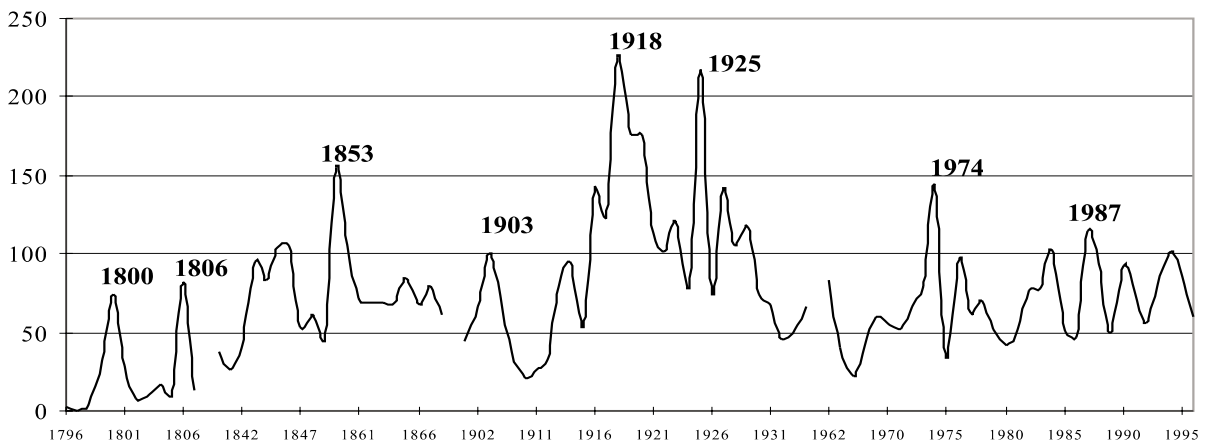

Figura 2. Evolução das exportações brasileiras de óleo de copaíba 
\% Exportações por país

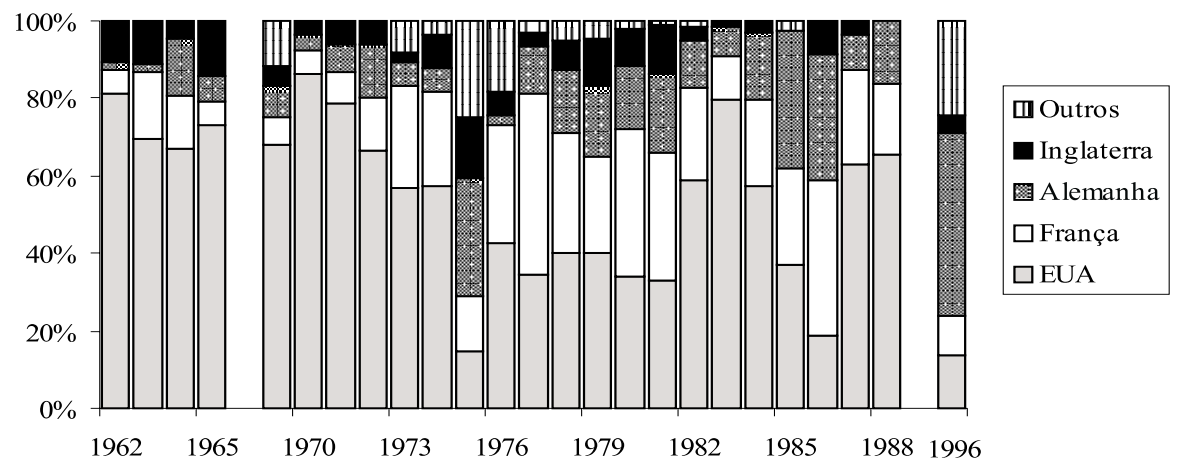

Ano

Figura 3. Participação dos principais países importadores de óleo de copaíba no volume total exportado pelo Brasil

misturas de substâncias poliaromáticas ${ }^{138}$. Por ser uma fonte rica e renovável de hidrocarbonetos, o uso do óleo de copaíba como combustível ecologicamente limpo tem sido extensamente avaliado. Calvin ${ }^{139-142}$ e Sierra ${ }^{143}$ descreveram as potencialidades do óleo como combustível, utilizado diretamente em mistura com óleo diesel numa proporção de 9 litros de óleo diesel para 1 litro de copaíba. Há também indicações na literatura da utilização do óleo de copaíba como aditivo para butadieno na confecção de borracha sintética ${ }^{144}$ e como inibidor de corrosão de aço em solução salina ${ }^{145}$. O óleo tem sido utilizado também como fonte de substrato quiral na síntese de biomarcadores de sedimentos e resíduos de petróleo ${ }^{146}$.

Devido à grande quantidade de aplicações, muitos estudos se detiveram na avaliação do potencial de produção dos óleos de copaíba. Alencar realizou estudos silviculturais de regeneração natural das árvores $^{147}$, germinação ${ }^{148}$ e produção de óleos ${ }^{15}$. Em espécies de $C$. multijuga, observou que a espécie apresenta alta percentagem de germinação $(87,5 \%)$ e que a produção de óleo-resina, a qual alcançou 7 litros por ano em uma das árvores, é ideal para a comercialização com fins medicinais. Para finalidades energéticas, entretanto, seria necessário o estabelecimento de plantações com sementes de árvores-mãe, ou seja, espécimes que apresentassem uma maior produção do óleo ${ }^{15}$. Estudos populacionais e de germinação também foram realizados em espécies de C. langsdorfii ${ }^{149}$, C. publifora $^{150}$.

A casca da copaíba também encontra aplicações na tintura caseira, de onde se retira um corante amarelo, mediante cocção, utilizado para colorir fios de algodão ${ }^{151}$.

\section{COMPOSTOS DETECTADOS NO GÊNERO Copaifera}

Os estudos mais antigos acerca do óleo de copaíba datam do início do século XIX. Schweitzer, em 1829, foi o primeiro a descrever a solidificação do óleo de copaíba em uma substância que cristalizava após longo tempo em repouso. A esta substância deu o nome de ácido copaívico ${ }^{152}$. Flückiger observou um depósito similar no óleo de Copaifera officinalis, em Trinidad ${ }^{19}$. Fehling, em 1841, obteve um depósito cristalino diferente de uma copaíba do Pará, a que ele deu o nome de ácido oxycopaívico, de fórmula molecular $\mathrm{C}_{20} \mathrm{H}_{28} \mathrm{O}_{3}{ }^{19}$. Strauss ${ }^{19,152}$, em 1865 , isolou outro ácido cristalino, de fórmula $\mathrm{C}_{22} \mathrm{H}_{34} \mathrm{O}_{4}$, a que ele chamou de ácido meta-copaívico, com fusão entre $205{ }^{\circ} \mathrm{C}$ e $206{ }^{\circ} \mathrm{C}$. Já no século XX, Tschirch encontrou os dois ácidos acima descritos, misturados a outros, não cristaliza$\operatorname{dos}^{19}$. Keto, seu colaborador, descobriu outros dois ácidos no óleo de copaíba do Pará, a que chamou de ácido paracopaívico, de fórmula $\mathrm{C}_{20} \mathrm{H}_{32} \mathrm{O}_{3}$, de ponto de fusão entre $142{ }^{\circ} \mathrm{C}$ e $145{ }^{\circ} \mathrm{C}$; e ácido homoparacopaívico, de fórmula $\mathrm{C}_{18} \mathrm{H}_{28} \mathrm{O}_{3}$, fundindo entre $111^{\circ} \mathrm{C} \mathrm{e}$ $112{ }^{\circ} \mathrm{C}^{19}$.
O único destes ácidos que encontra similar nos diterpenos isolados e identificados após o advento das técnicas espectroscópicas parece ser o ácido paracopaívico. Delle Monache ${ }^{153}, 70$ anos depois de Keto, isolou o ácido ent-11-hidróxi-labda-8(17), 13-dieno-15-óico (diterpeno D20, na Tabela 3) do óleo de Copaifera multijuga, endêmico na Região Amazônica, que possui a mesma fórmula molecular e a mesma faixa de ponto de fusão ${ }^{154}$.

Após o trabalho realizado por Tschirch e Keto, em $1901^{155}$, Deussen em $1912^{99,156}$, Gildeheister, em $1931^{124}$, Freise, em $1937^{99}$ e Gottlieb e Iacham, em $1945^{157}$, realizaram estudos de densidade, solubilidade, índices de acidez e saponificação de óleos de copaíba de diferentes espécies, assim como da essência, separada por arraste a vapor ${ }^{157}$.

A composição química dos óleos de copaíba encontra-se definida em vários trabalhos, onde foram utilizadas técnicas mais antigas, bem como metodologias modernas de isolamento e de identificação, tais como cromatografia líquida de alta eficiência (HPLC) ${ }^{158}$, cromatografia com fluido super-crítico com detetor de infravermelho (SFC-FT-IR) ${ }^{159}$ e cromatografia gasosa acoplada à espectrometria de massas com colunas cromatográficas de fase estacionária quiral ( $\beta$ ciclodextrina permetilada) ${ }^{160}$. Constatou-se serem os óleos constituídos por misturas de sesquiterpenos, predominantes na maioria deles, e de diterpenos ${ }^{161}$.

A Figura 4 ilustra um cromatograma típico de óleo de copaíba, obtido através de cromatografia gasosa de alta resolução, com coluna de baixa polaridade. Neste cromatograma, sesquiterpenos (eluídos entre 8 e 13 minutos) e diterpenos (eluídos entre 20 e 26 minutos) são observados nas duas regiões de eluição.

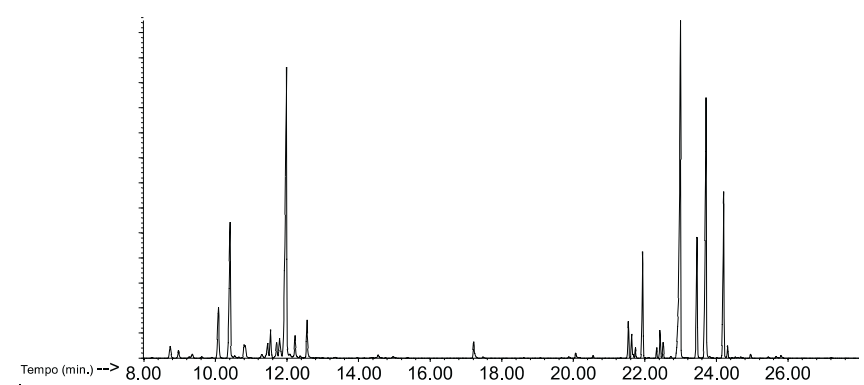

Figura 4. Cromatograma típico de óleos de copaíba

Pinto e colaboradores ${ }^{162}$ adaptaram a metodologia originalmente desenvolvida por McCarthy e Duthie ${ }^{163}$, utilizando coluna cromatográfica de sílica impregnada com $\mathrm{KOH}$ para a separação de ácidos carboxílicos em biolipídios (que foi depois modificada por Ramijak e Arpino para a separação de ácidos de alfaltos ${ }^{164}$ ). Esta adaptação foi 
utilizada na separação dos componentes do óleo de copaíba por classes de substâncias em: hidrocarbonetos, álcoois e ácidos carboxílicos, de acordo com o solvente utilizado para eluição da coluna ${ }^{165}$.

A maioria dos estudos realizados com óleos de copaíba visaram sua aplicação comercial na indústria de perfumes e cosméticos. A fração responsável pelo aroma do óleo de copaíba corresponde à dos sesquiterpenos. Estes compostos foram exaustivamente estudados e, hoje, o valor de concentrados de sesquiterpenos de Copaifera chega a ser 600 vezes maior do que o do óleo bruto ${ }^{166}$. Os sesquiterpenos são geralmente identificados por cromatografia gasosa de alta resolução (CGAR), através da comparação de seus índices de kóvats ${ }^{126}$. Óleos comerciais, obtidos de várias regiões do Brasil, foram analisados por CGAR, espectrometria de massas, mostrando uma grande quantidade sesquiterpenos (mais de 40) e diterpenos, provavelmente fruto de misturas de óleos de diversas espécies do gênero ${ }^{126}$. Alguns estudos citam o óleo essencial, obtido através da destilação direta, à pressão reduzida ou por arraste de vapor do óleo-resina, como o verdadeiro óleo de copaíba. Veiga Jr. e Pinto ${ }^{167}$ estudaram os óleos obtidos por diversas técnicas de destilação dos óleos de Copaifera multijuga e analisaram a composição da resina e da fração sesquiterpênica, verificando degradações provenientes do processo de destilação.

A Tabela 2 descreve os sesquiterpenos já encontrados nos óleos de Copaifera. Os compostos são citados como encontrados na literatura. Muitas das citações não diferenciam isômeros e apenas descrevem os compostos com nomes genéricos, como é o caso do cadineno, descrito somente como cadineno e também como $\alpha$-cadineno, $\delta$ cadineno e $\gamma$-cadineno. No óleo de $C$. cearensis um novo sesquiterpeno foi identificado: a avaliação olfatométrica através de cromatografia gasosa e análise de diluição do aroma no extrato (CGSniffing port-AEDA) levaram à identificação do álcool 1,5-dimetil8-isopropilciclodeca-1,4-dieno-8-ol (S29) como sendo o principal constituinte do aroma, juntamente com o ledol e óxido de cariofileno, com contribuição secundária ao aroma total ${ }^{168}$.

Alguns compostos encontrados em óleos de copaíba apresentam aromas marcantes, sendo utilizados pela indústria de perfumes, como o $\alpha$-humuleno ${ }^{169}$, cariofileno $^{170}, \alpha$-e $\beta$-selineno e $\beta$-bisaboleno ${ }^{171}$. Entre os sesquiterpenos que foram encontrados em óleos de copaíba, $\alpha$ copaeno, $\beta$-cariofileno, $\beta$-bisaboleno, $\alpha$ e $\beta$-selineno, $\alpha$-humuleno e $\delta$ e $\gamma$-cadineno foram descritos em grande parte dos óleos estudados.

Alguns autores ${ }^{172}$ relacionam a variação na composição dos óleos em função de fatores bióticos externos, tais como a injúria provocada por insetos ou fungos ${ }^{68}$. Um exemplo seria a produção de $\beta$-cariofileno, que é particularmente efetivo contra lepidópteros, e de seu óxido, que atua diretamente na inibição de fungos. As variações na composição sesquiterpênica dos óleos, porém, são muito grandes, descritas durante a maturação, ocorrendo sazonalmente em uma árvore, numa mesma espécie e entre espécies ${ }^{172}$. A presença de $\alpha$-copaeno ou $\alpha$-ilangeno nos óleos de copaíba, usualmente detectada através de cromatografia gasosa de alta resolução (CGAR), só pode ser confirmada utilizando-se a injeção realizada diretamente na coluna (On-Column), nas análises por CGAR, uma vez que os dois compostos sofrem isomerização durante a vaporização no injetor. A presença das duas séries de estereoisômeros entre os sesquiterpenos de óleos de copaíba é relatada na literatura ${ }^{160}$ para o $\alpha$-copaeno, como $99 \%$ dextrógiro (+) e 1\% levógiro (-). A presença majoritária do isômero (+) é importante pois somente o $(+)$ - $\alpha$-copaeno é efetivo na atração da mosca de fruta do Mediterrâneo, uma praga que ataca frutas e flores na Europa ${ }^{160}$.

Apesar da extensa literatura sobre óleos de copaíba, poucas referências discriminam a espécie de Copaifera que está sendo estudada. Somente 5 espécies têm sua composição química descrita na literatura. Muitos artigos não definem o local da coleta do óleo e outros citam locais onde a espécie não é endêmica. As espécies de Copaifera estudadas com identificação botânica, de acordo com sua localização, são: $C$. multijuga Hayne, abundante na região Amazônica, $C$. langsdorfii Desf., encontrada na região do cerrado, no nordeste, centro-oeste e sudeste brasileiro, C. cearensis Huber ex Ducke, nordeste brasileiro e $C$. officinalis L. e $C$. reticulata Ducke encontradas ao norte da Amazônia ocidental na região que se estende até a Venezuela ${ }^{5}$.

Os 28 diterpenos, descritos nos óleos de copaíba estudados, pertencem aos esqueletos caurano, labdano e clerodano (Figura 5). Em estudo realizado com diversos óleos de copaíba provenientes de várias regiões do Brasil, o ácido copálico foi o único encontrado em todos os óleos analisados ${ }^{126}$. Por esta razão, este diterpeno ácido pode ser usado como biomarcador de óleos de copaíba ${ }^{126}$.

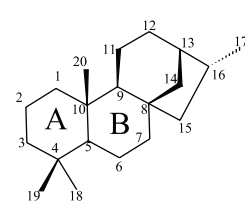

CAURANO

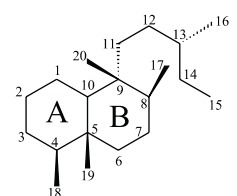

CLERODANO

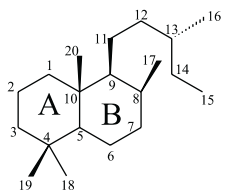

LABDANO
Figura 5. Numeração e estereoquímica normal dos esqueletos diterpênicos: caurano, clerodano e labdano. Sistema decalínico representado pelos anéis $A$ e $B$

As estruturas dos cauranos, clerodanos e labdanos já detectados nos óleos de copaíba são apresentadas nas Figuras 6, 7 e 8, respectivamente. Somente dois cauranos foram descritos: os ácidos 19-entcauranóico (D1) e 19-ent-caurenóico (D2). O número de clerodanos e labdanos descritos de Copaifera é bastante próximo (12 e 13, respectivamente). Um dos aspectos estruturais mais marcantes nestes diterpenos é a presença das duas séries de enantiômeros entre labdanos e clerodanos. É descrito também o clerodano D14, com diferente estereoquímica da junção dos anéis A e B da decalina, apresentando o carbono 19 na posição $\beta$ (vide Figura 7). A presença de anel furano ou lactona na cadeia lateral é bastante comum, aparecendo em metade dos clerodanos detectados, nos labdanos, e também no ácido patagônico, D25.

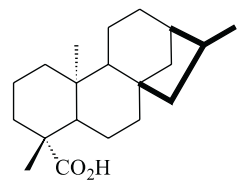

D1

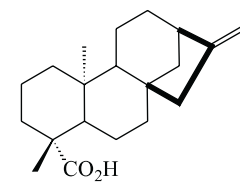

D2
Figura 6. Estruturas dos cauranos encontrados em óleos de copaíba

Nos esqueletos clerodano e labdano foram encontrados compostos da série normal (D3 a D6 e D15 a D19, Figuras 7 e 8, respectivamente) e da série enantio (D7 a D14 e D20 a D27, respectivamente). Hidroxilas e carboxilas são encontradas nas posições 3, 11, 15 e 18 e em 15,18 e 19, respectivamente, com insaturações mais comuns em 3-4, 7-8, 8-17 e 13-14.

Norlabdanos e carbonilas cetônicas são descritos em somente uma publicação ${ }^{185}$ (o dinorlabdano D18), isolados de um óleo de copaíba comercial. Nesta mesma publicação, um clerodano acetilado pouco comum nos óleos de copaíba, também foi descrito (D9).

Não só os óleos exudados do tronco das copaibeiras foram estudados quimicamente. Langenheim ${ }^{68}$ e colaboradores realizaram estudos quimiossistemáticos, buscando relacionar os padrões de variação da composição dos sesquiterpenos dos óleos de $C$. multijuga, $C$. langsdorfii, $C$. officinalis e $C$. pubiflora e a encontrada na resina extraída de suas folhas, obtida por técnicas de arraste a vapor. A 
Tabela 2. Sesquiterpenos já detectados em óleos de copaíba

\begin{tabular}{|c|c|c|}
\hline $\mathrm{N}^{\mathrm{o}}$ & Sesquiterpeno & Referência \\
\hline$\overline{\mathrm{S} 1}$ & Alo-Aromadendreno & $66,138,140,168,174$ \\
\hline $\mathrm{S} 2$ & Ar-Curcumeno & $66,140,168,174$ \\
\hline S3 & $\alpha$-Bergamoteno & $66,140,159,168,174$ \\
\hline S4 & $\beta$-Bergamoteno & 138,175 \\
\hline S5 & Biciclogermacreno & 66 \\
\hline S6 & $\beta$-Bisaboleno & $66,138,140,159,168,173,174,175,176,177,178,184$ \\
\hline S7 & $\beta$-Bisabolol & 66,138 \\
\hline $\mathrm{S} 8$ & $\alpha$-Bourbouneno & 176 \\
\hline S9 & Cadaleno & 138 \\
\hline $\mathrm{S} 10$ & Cadineno & 143,173 \\
\hline S11 & $\alpha$-Cadineno & 66 \\
\hline $\mathrm{S} 12$ & $\delta$-Cadineno & $66,135,138,140,168,174,175,178,179,180,181$ \\
\hline S13 & $\gamma$-Cadineno & $66,135,138,140,174,176,179,180,181,182$ \\
\hline $\mathrm{S} 14$ & $\alpha-C a d i n o l$ & 66 \\
\hline S15 & Calameneno & $66,138,174$ \\
\hline S16 & Calareno & 66 \\
\hline S17 & Cariofileno & $135,140,143,168,174,176,179,180,181,182,183$ \\
\hline S18 & $\beta$-Cariofileno & $66,138,159,173,175,177,178,184$ \\
\hline S19 & $\alpha$-Cariofilenol & 66 \\
\hline S20 & Cedrol & 66,138 \\
\hline $\mathrm{S} 21$ & $\alpha$-Cedreno & 66,168 \\
\hline $\mathrm{S} 22$ & Cipereno & $135,140,174,176,179,180,181,182$ \\
\hline $\mathrm{S} 23$ & Copaeno & 174,176 \\
\hline $\mathrm{S} 24$ & $\alpha$-Copaeno & $66,135,138,140,159,160,168,173,175,177,178,179,180,181,182,184$ \\
\hline $\mathrm{S} 25$ & $\beta$-Copaeno & $135,138,179,180,181$ \\
\hline S26 & Cubebeno & 173 \\
\hline S27 & $\alpha$-Cubebeno & $66,135,138,140,168,174,175,177,180,181,182,184$ \\
\hline S28 & $\beta$-Cubebeno & $66,140,168,174$ \\
\hline S29 & 1,5-Dimetil-8-isopropilciclodeca-1,4-dien-8-ol & 168 \\
\hline $\mathrm{S} 30$ & $\alpha$-Elemeno & 66 \\
\hline S31 & $\beta$-Elemeno & $66,138,140,168,173,174,184$ \\
\hline $\mathrm{S} 32$ & $\delta$-Elemeno & $138,140,174,178$ \\
\hline S33 & $\gamma$-Elemeno & 140,174 \\
\hline S34 & $\beta$-Farneseno & 140,174 \\
\hline S35 & trans- $\beta$-Farneseno & 175 \\
\hline S36 & Fonenol & 168 \\
\hline S37 & Germacreno B & 66 \\
\hline S38 & Germacreno D & 66,138 \\
\hline S39 & $\alpha$-Guaieno & 66,138 \\
\hline S40 & $\beta$-Guaieno & 138 \\
\hline S50 & $\gamma$-Guaieno & 138 \\
\hline S51 & Guaiol & 66 \\
\hline S52 & $\alpha$-Gurjuneno & 178 \\
\hline S53 & Himacheleno & 138 \\
\hline S54 & Humuleno & $159,176,184$ \\
\hline S55 & $\alpha$-Humuleno & $66,138,140,168,173,174,175$ \\
\hline S56 & $\beta$-Humuleno & $131,135,140,179,180,181,182,183$ \\
\hline S57 & $\gamma$-Humuleno & 177 \\
\hline S58 & Ledol & 66,168 \\
\hline S59 & Longicicleno & 66 \\
\hline S60 & Longifoleno & 66 \\
\hline S61 & Longipineno & 66 \\
\hline S62 & $\alpha$-Multijugenol & $66,173,177$ \\
\hline S63 & t-Muurolol & 168 \\
\hline S64 & $\alpha$-Muuroleno & 138,175 \\
\hline S65 & $\gamma$-Muuroleno & $135,138,179,180,181,182$ \\
\hline S66 & Óxido de cariofileno & $66,168,173,177,179,180$ \\
\hline S67 & $\alpha$-Selineno & $66,135,138,140,168,174,179,180,181$ \\
\hline S68 & $\beta$-Selineno & $135,138,140,168,174,177,180,181,182$ \\
\hline S69 & $\beta$-Sesquifelandreno & 66 \\
\hline S70 & Veridiflorol & 168 \\
\hline S71 & $\beta$-Vetiveneno & 66 \\
\hline S72 & $\alpha$-Ylangene & $138,173,177$ \\
\hline
\end{tabular}


Tabela 3. Diterpenos encontrados nos óleos de copaíba

\begin{tabular}{|c|c|c|}
\hline $\mathrm{N}^{\mathrm{o}}$ & Constituintes & Referências \\
\hline \multicolumn{3}{|c|}{ Cauranos } \\
\hline D1 & Ácido ent-16- $\beta$-caurano-19-óico & $176^{\mathrm{c}}, 186^{\mathrm{c}}$ \\
\hline D2 & Ácido ent-caura-16-eno-19-óico & $176^{\mathrm{c}}$ \\
\hline \multicolumn{3}{|c|}{ Clerodanos } \\
\hline D3 & Ácido 3,13-clerodadieno-15,16-olídeo-18-óico (Ácido patagônico) & $162^{\mathrm{b}}, 165^{\mathrm{b}}$ \\
\hline D4 & Ácido 3-clerodeno-15,18-dióico & $162^{\mathrm{b}}, 165^{\mathrm{b}}$ \\
\hline D5 & Ácido 13-clerodeno-15,16-olídeo-18-óico & $162^{\mathrm{b}}, 165^{\mathrm{b}}$ \\
\hline D6 & Ácido clerodano-15,18-dióico & $165^{\mathrm{b}}$ \\
\hline D7 & Ácido ent-15,16-epóxi-13(16),14-clerodadieno-18-óico (Ácido clorechínico) & $162^{\mathrm{b}}, 165^{\mathrm{b}}, 186^{\mathrm{c}}$ \\
\hline D8 & Ácido ent-15,16-epóxi-3,13(16),14-clerodatrieno-18-óico (Ácido hardwíckiico) & $119^{\mathrm{b}}, 186^{\mathrm{c}}, 187^{\mathrm{c}}, 188^{\mathrm{e}}, 189^{\mathrm{d}}$ \\
\hline D9 & $\begin{array}{l}\text { Ácido 15,16-epóxi-7 } \beta \text {-acetóxi-3,13(16),14-clerodatrieno-18-óico } \\
\text { (Ácido 7-acetóxi-hardwíckiico; 7a-acetoxibacchotriconeatina D) }\end{array}$ & $185^{\mathrm{a}}, 190^{\mathrm{a}}$ \\
\hline D10 & Ácido 3,13-clerodadieno-15-óico (Ácido colavênico) & $162^{\mathrm{b}}, 165^{\mathrm{b}}, 186^{\mathrm{c}}$ \\
\hline D11 & 3,13-clerodadieno-15-ol (Colavenol) & $187^{\mathrm{c}}$ \\
\hline D12 & Ácido ent-15,16-epóxi-7ß-hidróxi-3,13(16),14-clerodatrieno-18-óico (Ácido 7-hidróxi-hardwíckiico) & $189^{\mathrm{d}}$ \\
\hline D13 & ent-(19a)-3,13-clerodadieno-15-ol (cis-colavenol) & $187^{\mathrm{c}}$ \\
\hline D14 & ent-neo-4(18), 13-clerodadien-15-ol & $187^{\mathrm{c}}$ \\
\hline \multicolumn{3}{|c|}{ Labdanos } \\
\hline D15 & Ácido 18-hidróxi-8(17), 13-labdadieno-15-óico (Ácido copaiferólico) & $177^{\mathrm{d}}$ \\
\hline D16 & Ácido 8(17), 13E-labdadieno-15-óico (Ácido copaiférico) & $189^{\mathrm{d}}$ \\
\hline D17 & Ácido (13S)-7-labdeno-15-óico (Ácido catívico) & $162^{\mathrm{b}}, 165^{\mathrm{b}}, 186^{\mathrm{c}}$ \\
\hline D18 & $3 \beta$-hidróxi-15,16-dinorlabda-8(17)-eno-13-ona & $185^{\mathrm{a}}$ \\
\hline D19 & 8(17), 13-labdadieno-15-ol & $187^{\mathrm{c}}$ \\
\hline D20 & Ácido ent-11-hidróxi-labda-8(17), 13-dieno-15-óico (Ácido 11-hidróxi-copálico) & $66^{\mathrm{d}}, 177^{\mathrm{d}}$ \\
\hline D21 & Ácido ent-3-hidróxi-labda-8(17),13-dieno-15-óico & $191^{\mathrm{a}}$ \\
\hline D22 & Ácido ent-8(17),13-labdadieno-15,19-dióico (Ácido ent-agático) & $66^{\mathrm{d}}, 186^{\mathrm{c}} 191^{\mathrm{a}}$, \\
\hline D23 & Ácido ent-8(17)-labdeno-15-óico (Ácido eperúico) & $162^{\mathrm{b}}, 165^{\mathrm{b}}, 186^{\mathrm{c}}$ \\
\hline D24 & Ácido ent-8(17)-labdeno-15,18-dióico (Ácido eperu-8 (20)-15, 18-dióico) & $176^{\mathrm{c}}$ \\
\hline D25 & Ácido ent-15,16-epóxi-8(17), 13(16),14-labdatrieno-18-óico (Ácido poliáltico) & $176^{\mathrm{c}}$ \\
\hline D26 & Ácido ent-8(17)-13E-labdadieno-15-óico (Ácido copálico) & $\begin{array}{l}66^{\mathrm{d}}, 162^{\mathrm{b}}, 165^{\mathrm{b}}, 184^{\mathrm{a}} \\
186^{\mathrm{c}}, 187^{\mathrm{c}}, 191^{\mathrm{a}}, 192^{\mathrm{b}}\end{array}$ \\
\hline D27 & Ácido ent-11-acetóxi-8(17)-13E-labdadieno-15-óico (Ácido 11-acetóxi-copálico) & $66^{\mathrm{d}}, 186^{\mathrm{c}}$ \\
\hline
\end{tabular}

a - Sem identificação da espécie; b - Isolado de C. cearensis; c - Isolado de C. langsdorfii; d - Isolado de C. multijuga; e - Isolado de C. officinalis<smiles>O=C1OCC2C1CCC1C2CC[C@@]23CCC=CC2(C(=O)O)CCC13</smiles><smiles>CC1CCC2C(CCC3C(C(=O)O)CCCC23)C1</smiles><smiles>CC(=O)OC1CC2C(C(=O)O)=CCCCC2(C)C2CCc3ccoc3CC12</smiles>

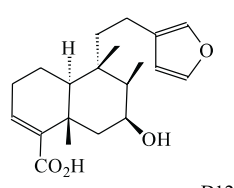<smiles>CC1CCC2C(CCC3C(C(=O)O)=CCCC32)C1</smiles><smiles>O=C(O)C1CCCCC12CCc1cocc1CC21CCO1</smiles><smiles>CC1=CCCC2(C)C1CCCC1C(C)=C(C)CCC12</smiles><smiles>CC1=CCCC2C3CCC(C)=C(CO)C3CCC12C</smiles>

D13<smiles>CC12CCCC(C(=O)O)C1CCC1C3CCC4C(=O)OCC4C3CCC12</smiles><smiles>O=C(O)C1=CCCC2CCc3cocc3CCC12</smiles><smiles>CC1=CCCC2C1CCC1C(C)=CCCC12</smiles>

D11<smiles>C=C1CCCC2[C@H]3CCC(C)=C(CO)C3CCC12C</smiles>

Figura 7. Estruturas dos clerodanos encontrados em óleos de copaíba 


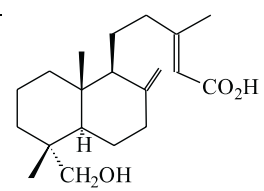

D15<smiles>CC(=O)CCC1C(C)CCC2C(C)C(O)CCC12C</smiles>

D18<smiles>CC1=C(C(=O)O)C2CCC3C(CCC(O)C3(C)C)C2CC1</smiles>

D21<smiles>CC(CCC1C(CC(=O)O)CCC2(C(=O)O)C(C)CCCC12)CC(=O)O</smiles>

D24<smiles>CC1=CC2CC[C@H]3C(C)CCCC3(C)C2CC1</smiles>

D16<smiles>CC1=C(CO)[C@H]2CC[C@H]3C(C)CCCC3(C)[C@@H]2CC1</smiles>

D19<smiles>CC1=C(C(=O)O)C2CCC3(C(=O)O)C(CCCC3(C)C)C2CC1</smiles>

D22<smiles>CC1CCC(C)(C(=O)O)[C@H](CCc2ccoc2)C1</smiles>

D25<smiles>CC(=O)OC[C@H]1CC(C)=C(C(=O)O)CCC1C1CCCC(C)(C)[C@@H]1C</smiles>

D27<smiles>CC1CCC2C(CC(=O)O)=CCC3C(C)(C)CCCC23C1</smiles>

D17<smiles>CC1=C(C(=O)O)C2CCC3C(CCCC3(C)C)C2CC[C@H]1O</smiles>

D20<smiles>CC1CCC2C(CCC3C2CCCC3(C)C)C1CC(=O)O</smiles>

D23<smiles>CC1=C(C(=O)O)C2CC[C@@H]3[C@@H](CCCC3(C)C)[C@@H]2CC1</smiles>

D26

Figura 8. Estruturas dos labdanos encontrados em óleos de copaíba

composição e produção dos óleos em relação a variações diurnas ${ }^{172}$, sazonais $^{179,180}$, de intensidade de luz ${ }^{181}$ e nutrientes do solo e em comparação com gêneros correlatos como Hymenaea, foram extensamente relatados por estes autores, que descrevem a presença de hidrocarbonetos e álcoois sesquiterpênicos e fenóis ${ }^{193}$.

Estudos fitoquímicos foram também realizados com as sementes de Copaifera salikounda Heck., uma espécie do sul da África Ocidental ${ }^{194}$, sendo detectadas cumarinas. Em estudos mais recentes realizados com o óleo das sementes de uma espécie de Copaifera brasileira foram encontrados cumarinas $(0,15 \%)$ e os ácidos palmítico $(24,9 \%)$, oléico $(35,3 \%)$, linoléico $(35,7 \%)$, araquidínico $(1,1 \%)$ e beênico $(3,0 \%)^{173}$. Estudos realizados com óleos de sementes de $C$. langsdorfii mostraram a presença da cumarina umbeliferona ${ }^{173}$ e de oligossacarídeos xiloglucânicos ${ }^{195,196}$ com rendimento de $40 \%$ do peso seco da semente e alto peso molecular $(2.000 .000)^{197}$.

Aminoácidos não proteicos, como o N-metil-trans-4-hidroxi-L prolina, foram encontrados como cerca de $2-3 \%$ do peso seco das folhas das espécies C. langsdorfii, C. multijuga, C. pubiflora, $C$. venezuelana e C. officinalis ${ }^{198}$.

\section{PROPRIEDADES MEDICINAIS}

O Food and Drug Administration (FDA), órgão de regulamentação de drogas e alimentos do governo americano, aprovou o óleo de copaíba em $1972^{199}$. Testes de irritação e sensibilização do óleo de copaíba foram realizados com 25 voluntários, não se observando estes tipos de reação ${ }^{200}$.

Entre as propriedades medicinais dos óleos de copaíba a mais estudada foi a antiinflamatória. Zanini e colaboradores ${ }^{184}$ estudaram a atividade antiinflamatória do óleo em ratos utilizando diversos modelos, como inibição de edema induzido por carragenina, inibição de formação de granuloma "Cotton-pellet" e aumento de permeabilidade vascular. Seus resultados indicam que o óleo possui atividade antiinflamatória e baixa toxidez $\left(\mathrm{DL}_{50} 3.79 \mathrm{ml} / \mathrm{kg}\right)$. Apesar dos efeitos adversos por altas doses do óleo (irritação gastro-intestinal, diarréia, sialorréia e depressão do sistema nervoso central), seu uso é plenamente justificado na medicina popular. O estudo feito por Zanini e colaboradores ${ }^{184}$ foi realizado com óleo comercial, sem identificação botânica da espécie que o produziu.

Fernandes e colaboradores ${ }^{192}$ estudaram o efeito analgésico e antiinflamatório dos óleos de Copaifera cearensis, comparado-os com os da indometacina e com o de alguns derivados isolados de óleos de copaíba como o ácido copálico, o éster metílico do ácido solidago e bisabolol. Os resultados do estudo indicam que o óleo possui atividades antiinflamatória e analgésica maiores que aquela dos três compostos estudados isoladamente, porém menores que as da indometacina ${ }^{192}$.

Estudos recentes realizados com diversos óleos de copaíba comerciais ${ }^{201}$ e de Copaifera multijuga mostram que a fração que contém hidrocarbonetos tem maior atividade antiinflamatória do que as frações de álcoois sesquiterpênicos e ácidos diterpênicos. 
Óleos de copaíba comerciais mostraram atividades de proteção contra a penetração de cercárias de Schistosoma mansoni ${ }^{202}$, e como cercaricida $^{191,203}$, piscicida ${ }^{191}$ e repelente de insetos ${ }^{204,205}$. Atividades antimicrobiana e antibacteriana ${ }^{206,207,208,209,210,211}$ também são relatadas na literatura.

Estudos de absorção na pele de camundongos, entretanto, mostraram que a absorção percutânea do óleo de copaíba é muito lenta, por volta de noventa e dois minutos ${ }^{212}$.

A atividade anti-tumoral de óleos de Copaifera langsdorfii foi observada contra carcinoma IMC, em camundongos ${ }^{187}$. O fracionamento guiado por bioensaio mostrou que os diterpenos colavenol (D11) e o ácido hardwíckico (D8) apresentam potente atividade anti-tumoral, sem, contudo, apresentarem citotoxicidade contra as mesmas células ${ }^{187}$. Para os óleos de $C$. multijuga a atividade anti-tumoral vem sendo estudada in vivo e in vitro, sendo observada esta atividade também para o óleo desta espécie. Nestes estudos, o óleo de $C$. multijuga tem inibido o crescimento tumoral (melanoma murino B16F10) através da redução da formação dos nódulos de metástase no tecido pulmonar ${ }^{213}$. Experimentos de viabilidade celular, realizados in vitro com este mesmo óleo, mostram uma significativa redução no número de células de melanoma viáveis ${ }^{213}$. O óleo de Copaifera multijuga mostrou-se também tóxico e com potente atividade antitumoral tempo e dose dependente em ensaios contra células de mastocitoma murino P815 214 .

Óleos das espécies Copaifera multijuga, Copaifera cearensis e Copaifera reticulata foram avaliados também quanto às atividades antiinflamatória no modelo de pleurisia em camundongos, antineoplásica in vitro e tripanossomicida ${ }^{215}$.

No ensaio de atividade antiinflamatória a pleurisia é induzida por carragenina, LPS (lipopolissacarídeo extraído da parede de E.coli) ou reação alérgica. Na reação inflamatória induzida por carragenina, nenhum dos óleos testados foi capaz de inibir o extravasamento de proteínas plasmáticas ou a migração de células que ocorre 4 horas após o estímulo inflamatório. Na reação inflamatória induzida 24 h após a injeção de LPS ou estímulo alérgico (ovoalbumina em animais previamente sensibilizados), o óleo de Copaifera reticulata foi capaz de inibir significativamente a migração de eosinófilos, enquanto os outros dois óleos não apresentaram efeito na dose testada $(100 \mathrm{mg} / \mathrm{kg})^{215}$.

$\mathrm{Na}$ avaliação da atividade antineoplásica in vitro dos óleos destas três espécies, foi verificada a capacidade de inibição da proliferação da linhagem Sp2/0 (mieloma de camundongo). Os três óleos testados $(250 \mathrm{mg} /$ poço $)$ foram capazes de inibir significativamente a proliferação celular (medida através de incorporação de timidina $[\text { metil-3H }]^{215}$.

No ensaio de atividade tripanossomicida, estes três óleos foram colocados em contato $(250 \mathrm{mg} /$ poço $)$ com cultura de formas tripomastigotas de $T$. cruzi durante $48 \mathrm{~h}$. Observou-se que o óleo de Copaifera multijuga foi capaz de matar $100 \%$ dos parasitas, enquanto que os óleos de Copaifera cearensis e Copaifera reticulata mataram $87 \%$ dos T. cruzi, indicando uma potente atividade ${ }^{215}$.

A atividade gastroprotetora do óleo de Copaifera langsdorfii foi avaliada em lesões gástricas induzidas por etanol e indometacina. Ratos pré-tratados com o óleo desta copaíba foram protegidos em doses a partir de $400 \mathrm{mg} / \mathrm{kg}$. Os resultados obtidos sugerem que a ação deste óleo se deve à diminuição de acidez gástrica, provavelmente através da promoção da secreção de muco gástrico e bicarbonato $^{216}$. Estudos realizados com óleo de copaíba comercial em ratos mostraram a ocorrência de diarréia, perda de peso e ação irritante no comportamento de ratos em doses de $0,63 \mathrm{ml} / \mathrm{kg}^{217}$.

As propriedades cicatrizantes de feridas e úlceras, uma das principais indicações dos óleos de copaíba, foram estudadas em óleos comerciais por Brito ${ }^{218,219}$ e nos óleos de Copaifera langsdorfii, por $\mathrm{RaO}^{220}$.
Nos estudos de Brito, realizados em modelo de ferida aberta, os ratos que receberam óleo de copaíba na região dorsal apresentaram aumento de tecido de granulação e do número de vasos sanguíneos, porém, diminuição da quantidade de fibras colágenas ${ }^{218,219}$.

Nos experimentos realizados por Rao, o óleo mostrou-se bastante ativo nos ratos em modelos de ferida aberta, resistência à tensão e úlcera crônica de estômago, produzida por ácido acético ${ }^{220}$.

Uma das áreas em que se vem pesquisando intensamente a utilização do óleo de copaíba atualmente é a odontológica ${ }^{221-223}$. Bandeira estudou a composição do óleo essencial, separado da resina do óleo de Copaifera multijuga e sua compatibilidade biológica em molares de rato, associados ao hidróxido de cálcio como veículo ${ }^{224,225}$ e as atividades bactericida e bacteriostática das duas frações frente ao óleo bruto ${ }^{226}$. Os resultados de biocompatibilidade, obtidos com hidróxido de cálcio misturado ao óleo essencial do óleo de Copaifera multijuga, mostraram um melhor desempenho histopatológico que aquele com o hidróxido de cálcio misturado ao óleo de copaíba e ao polietilenoglicol, utilizado tradicionalmente ${ }^{225}$. Os estudos de atividade antibacteriana mostraram maiores atividades bactericida e bacteriostática do óleo de Copaifera multijuga, frente a Streptococcus mutans, enquanto o óleo essencial apresentou melhor ação bactericida e a resina apresentou-se apenas bacteriostática ${ }^{226}$.

Propriedades anti-oxidantes são descritas para o extrato metanólico das cascas de $C$. reticulata. Testado quanto à redução de radicais livres indutores de dano ao DNA, o extrato metanólico mostrou-se bastante ativo, apresentando $\mathrm{CI}_{50} 3 \mu \mathrm{g} / \mathrm{ml}$, menor que o padrão utilizado, catequina $\left(\mathrm{CI}_{50} 5 \mu \mathrm{g} / \mathrm{ml}\right)^{227}$. O potencial anti-oxidante reativo total deste extrato também foi analisado quanto à redução de radicais livres em ensaios de quimioluminescência, mostrando uma atividade de $7500 \mu \mathrm{M}$, em valores relativos ao padrão, Trolox ${ }^{228}$.

Extratos das sementes de C. multijuga foram analisadas quanto às atividades hemolítica e aglutinante, sendo que somente a primeira foi comprovada ${ }^{215}$.

Vários dos compostos já isolados ou detectados nos óleos de copaíba já tiveram propriedades farmacológicas, descritas na literatura. Entre os sesquiterpenos, alguns propriedades como anti-úlcera ${ }^{230}$, anti-viral ${ }^{231} \mathrm{e}$ anti-rinovírus $^{231}$ são descritas para o ar-curcumeno e o $\beta$-bisaboleno, este último também descrito como abortivo ${ }^{232}$. O bisabolol é conhecido por conferir as propriedades antiinflamatória e analgésica à camomila (Matricaria chamomilla) ${ }^{233}$, o $\beta$-elemeno é descrito como anticâncer (cérvico) ${ }^{234}$ e cariofileno e $\delta$-cadineno como anti-cariogênicos ${ }^{235}$, sendo este último também bactericida (CMI $800 \mathrm{ug} / \mathrm{ml})^{235}$.

Entre estes, entretanto, os que foram mais estudados e se mostraram ativos num maior número de ensaios foram o cariofileno e seu óxido. O cariofileno é descrito na literatura como: anti-edêmico ${ }^{236}$, fagorrepelente ${ }^{237}$, antiinflamatório $\left(\mathrm{CI}_{50}=100 \mathrm{uM}\right)^{236}$, antitumoral ${ }^{238}$, bactericida $^{239}$, insetífugo ${ }^{240}$ e anti-alérgico ${ }^{241}$. Algumas destas atividades são também conferidas ao óxido ${ }^{236,237,238}$, além de inseticida ${ }^{242}$.

O ácido caurenóico (D2) é descrito na literatura como tripanossomicida ${ }^{243}$, atividade conferida também a óleos de copaíba que não contêm este diterpeno ${ }^{230}$. Estudos realizados com ácido caurenóico isolado de Copaifera langsdorfii mostram também atividade relaxante do músculo liso, sobre contrações uterinas induzidas ${ }^{244}$.

\section{CONCLUSÃO}

Apesar da extensa literatura que trata dos óleos de copaíba, poucos são os artigos onde é encontrada a identificação botânica da espécie estudada. Os estudos de atividade biológica confirmam a sabedoria popular e o conhecimento adquirido dos índios pelos portugueses já no início da colonização. Poucos deles, porém, conseguem identificar os princípios ativos apesar de sugerirem que compostos fortemente ativos estão presentes. 
Tudo isso indica que apesar de toda a pesquisa já realizada, os óleos de copaíba são potencialmente importantes como fonte de princípios ativos em farmacologia.

\section{AGRADECIMENTOS}

Os autores agradecem ao professor Dr. R. B. de Alencastro, do Instituto de Química da UFRJ, ao doutor H. C. de Lima, do Jardim Botânico do Rio de Janeiro, à doutora M. A. Maciel e ao antropólogo D. Carrara pelas valorosas sugestões e pelo apoio financeiro concedido pelo CNPq, CAPES e PRONEX-FINEP 41.96,00911.004002-96.

\section{REFERÊNCIAS}

1. Judd, S. W.; Campbell, S. C.; Kellog, E. A.; Stevens, P. S.; Plant Systematics, A Phylogenetic Approach; Ed. Sinauer: Sunderland, 1999, p. 283.

2. Harborne, J.B.; Boulter, D.; Turner, B.L.; Chemotaxonomy of the Leguminosae; Academic Press: London, 1971, p. 1.

3. Lewis, W. H.; Elvin-Lewis, M. P. F.; Medical Botany; John Wiley and Sons: New York, 1977, p. 293.

4. Piso, G.; Marcgrave, J.; Hist. Pl. 1625, 3, 130.

5. Dwyer, J. D.; Brittonia 1951, 7, 143.

6. Jacquin; Enum. Pl. Carib. 1760, 65.

7. Linnaeus; Sp. Pl. 1762, 557.

8. Hayne; Arzneig 1825, 10, 16.

9. von Martius, F.; Bentham; Flora Brasiliensis 1870, 15, 240.

10. Ducke, A.; Boletim Técnico do Instituto Agronômico do Norte 1949, 18, 81.

11. Ducke, A.; Revue Bot. Appl. 1932, 12, 30.

12. Ducke, A.; An. Acad. Brasil. Ciências 1967, 30, 327.

13. Dwyer, J. D.; Bull. Torrey Bot. Club 1954, 81, 179.

14. Dwyer, J. D.; Tropical Woods 1945, 83,15.

15. Alencar, J. C.; Acta Amazonica., 1982, 12, 75.

16. Burkart, A.; Las leguminosas Argentinas; Acme Agency: Buenos Aires, 1943, p. 15.

17. Index Kewensis, suppl. XX; Claredon Press: Oxford, 1996.

18. Andrade Jr., M. A.; Ferraz, I. D. K.; Veiga Jr., V. F.; $51^{\circ}$ Congresso Nacional de Botânica da Sociedade Botânica do Brasil, Brasília, Brasil, 2000.

19. Wood, H. C.; LaWall, C. H.; Youngken, H. W.; Osol, A.; Griffith, I.; Gershenfeld, L.; The dispensatory of the United States of America, J. B. Lippincott Company: London, $22^{\mathrm{a}}$ ed., 1940, p. 369.

20. Mors, W.; Rizzini, C. T.; Useful Plants of Brazil; Holden-Day Inc.: San Francisco, 1966, p. 45.

21. Pio Corrêa, M.; Dicionário das Plantas Úteis do Brasil; Ministério da Agricultura; Rio de Janeiro, 1931, p. 370.

22. Souza, A. F. R. D.; Abreu, C. L. B.; Arq. Jard. Bot. Rio de Janeiro 1977, 20, 93.

23. Perrot, E.; Matières premières usuelles du Règne végétal; Tomo II, Masson et Cie. Éditeurs: Paris, 1994, p. 2344.

24. Leite, A. M. C.; Lleras, E.; Acta Bot. Bras. 1993, 7, 61.

25. Rowaan, P. A.; Verfkroniek 1943, 16, 60, (C.A. 38: 61155).

26. Roux, D. G.; Nature 1953, 183, 890.

27. Léonard, J.; Mem. Acad. R. Belg., Cl. Sci. 1957, 30, 1.

28. Milne-Redhead, E.; Kew Bull. 1934, 9, 400.

29. Léonard, J.; Bull. Jard. Bot. Brux. 1949, 19, 384.

30. Hou, D.; Blumea 1994, 38, 313.

31. Van den Berg, M. E.; Plantas Medicinais da Amazônia. Contribuição ao seu conhecimento sistemático; CNPq-MPEG: Brasília, 1982, p. 145.

32. Silva, M. F.; Lisbôa, P. L. B.; Lisbôa, R. C. L.; Nomes vulgares de Plantas da Amazônia; INPA: Belém, 1977, p. 72.

33. Baillon, H.; Dictionnaire de botanique, Tomo II; Hachette et Cie.: Paris, 1886.

34. Carvalho, P. E. R.; Espécies florestais brasileiras; recomendações silviculturais, potencialidades e uso de madeira; EMBRAPA/CNPF: Brasília, 1994, p. 640.

35. Santos, N.; Rodriguesia 1979, 31, 223.

36. Crestana, C. S. M.; Kageyama, P. Y.; Rev. Inst. Flor. 1989, 1, 201.

37. Barth, O. M.; Rev. Brasil. Biol. 1971, 31, 431.

38. Di Biretti, M. S.; Vidal, E. M.; Baldovino, M. C., Benesovsky, V.; Am. J. Primatol. 2000, 50, 257.

39. Crestana, C. M.; Beltrati, C. M.; Naturalia 1988, 13, 45.

40. Eira, M. T. S.; Salomão, A. N.; Cunha, R.; Mello, C. M. C.; Tanaka, D. M.; $2^{\circ}$ Congresso Nacional sobre Essências Nativas, Brasília, Brasil, 1992.
41. Barbosa, J. M.; Aguiar, I. B.; Santos, S. R. G.; $2^{\circ}$ Congresso Nacional sobre Essências Nativas, Brasília, Brasil, 1992.

42. Borges, E. E. L.; Borges, C. G.; Rev. Bras. Sem. 1979, 1, 45.

43. Bruneton, J.; Eléments de Phytochimie et de Pharmacognosie; Lavoisier: Paris, 1987, p. 585.

44. Figueiredo, E. R.; Chácaras e Quintaes 1935, 52, 82.

45. Bruneton, J.; Pharmacognosie, Phytochimie, Plantes méedicinales; Lavoisier: Paris, 1993, p. 915.

46. Robbers, J. E.; Speedie, M. K.; Tyler, V. E.; Pharmacognosy and Pharmacobiotechnology; Williams \& Wilkins: Baltimore, 1996, p. 100.

47. Oliveira, F. M. M.; Estudos de Matéria Médica Vegetal; Escola Typographica Salesiana: São Paulo, 1905, p. 114.

48. Le Conte, P.; Apontamentos sobre as sementes oleaginosas; Museu Comercial do Pará, 3a. ed., Belém, 1927, p. 47.

49. Matta, A. A.; Flora Medica Braziliense; Imprensa Oficial: Manaus, 1913, p. 318.

50. Silva, J. R. M.; Plantas Medicinais e Industriaes; Rio de Janeiro, 1923, p. 164.

51. Le Cointe, P.; Notes sur les Graines Oléagineuses, les Baumes et les Résines de la Forêt Amazonnienne; Paris, 1927, p. 28.

52. Perrot, E.; Matieres premieres usuelles de rezime végétal; vol. 2; Masson \& Cia: Paris, 1943, p. 1458.

53. Grieve, M.; A modern herbal; Tiger Books International: London, 1994, p. 221.

54. Carvalho, J. B. M.; O Norte e a indústria de óleos vegetais sob o aspecto técnico-econômico; Ministério da Agricultura; Rio de Janeiro, 1942, p. 135.

55. Loureiro, A.A.; Essências madeireiras da Amazônia, vol. 1; INPA/CNPq: Manaus, 1979, p. 125.

56. Cesar, G.; Curiosidades da Nossa Flora; Imprensa Oficial: Recife, 1956, p. 374.

57. Ducke, A.; As Leguminosas da Amazônia Brasileira; Ministério da Agricultura: Rio de Janeiro,1939, p. 56.

58. Silva, J. R. M.; Contribuição para o estudo da flora brasileira; Rio de Janeiro, 1911, p. 81.

59. Silva, J. R. M.; O Brasil e suas possibilidades; Rio de Janeiro, 1951, p. 174.

60. Rodrigues, J. B.; Hortus Fluminensis; Rio de Janeiro, 1894, p. 307.

61. Rodrigues, R. M.; A flora da Amazônia, Ed. Cejup: Belém, 1989, p. 463.

62. Penna, M.; Dicionário Brasileiro de Plantas Medicinais, $3^{\mathrm{a}}$ ed.; Liv. Kosmos: Rio de Janeiro, 1946, p. 409.

63. Medeiros, D. F.; Xavier Filho, L.; Barbosa Filho, J. M.; Bol. Soc. Brot. 1985; Sér. 2, 58, 43.

64. Mattos Filho, A.; Rizzini, C. T.; Mautone, L.; Guimarães, E. F.; Árvores do Jardim Botânico; Ed. Lidador: Rio de Janeiro, 1993, p. 67.

65. Lawrence, B. M.; Progress in essential oil. Natural Flavor and Fragance Materials 1980, 5, 32.

66. Veiga Jr., V. F.; Dissertação de Mestrado, Universidade Federal do Rio de Janeiro, Brasil, 1997.

67. Gândavo, P. M.; História da Província de Santa Cruz a que vulgarmente Chamamos Brasil; Oficina Antônio Gonsaluez: Lisboa, 1576, p. 18.

68. Langenheim, J. H.; Am. Sci. 1990, 78, 16.

69. Maximiliano; Viagem ao Brasil; Companhia Editora Nacional; $2^{\text {a }}$ ed., São Paulo, 1958, p. 536.

70. Rosa, J. F.; Tratado Único da Constituição Pestilencial de Pernambuco; Lisboa, 1694, p. 37.

71. Langgaard, T. J. H.; Novo Formulário Médico e Farmacêutico; Ed. Laemmert: Rio de Janeiro, 1872, p. 1220.

72. O Tupi na Geografia Nacional; $3^{\text {a }}$ ed., Bahia, 1928, p. 190

73. Peckolt, G.; Revista Flora Medicinal 1942, 9, 453.

74. Léry, J., Histoire dún voyage fait en la terre du Brésil-1557; Lestringant, F., ed.; Max Chaleil: Paris, 1578, re-ed. 1992; p 263.

75. Grande Enciclopédia Larrousse Cultural, 1998, p. 1608.

76. Von Martius, C. F. P.; Systema de Materia Medica Vegetal; Eduardo \& Henrique Laemmert: Rio de Janeiro, 1854, p. 206.

77. Cardim, F.; Do clima e Terra do Brasil, 1584, p. 21, apud Cunha, A. G.; Dicionário Histórico das Palavras Portuguesas de Origem Tupi, $4^{\mathrm{a}}$ ed.; Companhia Melhoramentos: Brasília, 1998, p. 112.

78. Salvador, V.; História do Brasil: 1500-1627, 6ª ed.; Melhoramentos: São Paulo, 1975, p. 65.

79. Barléu, G.; Historia dos feitos recentemente praticados durante oito anos no Brasil, vol. 15; Coleção Reconquista do Brasil; Ed. Itatiaia: Belo Horizonte, 1974, p. 141.

80. Marcgrave, J.; Historia Natural do Brasil, Imprensa Oficial do Estado; São Paulo, 1942, p. 130.

81. Piso, G.; Historia Natural e Médica da Índia Ocidental; MEC: Rio de Janeiro, 1957, p. 270.

82. Carrara Jr., E.; Meirelles, H.; A Indústria Química e o Desenvolvimento do Brasil - 1500-1889; Metalivros: São Paulo, 1996, p. 115. 
83. Acosta, J.; História Natural e Moral das Índias; Madrid, 1792, p. 253.

84. Rodrigues, L.; Anchieta e a medicina; Edições Apollo: Belo Horizonte, 1934 , p. 361.

85. Vogt, C.; Lemos, J. A. G.; Cronistas e Viajantes; vol. I, Ed. Abril: São Paulo, 1982, p. 30.

86. Soares, F.; Coisas Notáveis do Brasil, 1590, apud Cunha, A. G.; Dicionário Histórico das Palavras Portuguesas de Origem Tupi, $4^{\mathrm{a}}$ ed., Companhia Melhoramentos: Brasília, 1998, p. 112.

87. Travaços, S.; Declaração do Brasil, 1596, p. 37, apud Cunha, A. G.; Dicionário Histórico das Palavras Portuguesas de Origem Tupi, $4^{\mathrm{a}}$ ed., Companhia Melhoramentos: Brasília, 1998, p. 112.

88. Rodrigues, J.; Relação = A Missão Carijó, apud Leite, S.; Novas Cartas Jesuíticas, 1607, apud Cunha, A. G.; Dicionário Histórico das Palavras Portuguesas de Origem Tupi, $4^{\mathrm{a}}$ ed., Companhia Melhoramentos: Brasília, 1998, p. 112.

89. Silveira, S. E.; Relação do Maranhão, 1624, p. 12, apud Cunha, A. G.; Dicionário Histórico das Palavras Portuguesas de Origem Tupi, $4^{\mathrm{a}}$ ed., Companhia Melhoramentos: Brasília, 1998, p. 112.

90. Morão, S. P.; Queixas de Pernambuco, 1677, em: Cunha, A. G.; Dicionário Histórico das Palavras Portuguesas de Origem Tupi, $4^{\mathrm{a}}$ ed., Companhia Melhoramentos: Brasília, 1998, p. 113.

91. Ming, L. C.; Dissertação de Doutorado; Universidade Estadual Paulista, Brasil, 1995.

92. Braga, R.; Plantas do Nordeste, especialmente do Ceará; $3^{\mathrm{a}}$ ed., Fortaleza, 1960, p. 401.

93. Fonseca, E. T.; Óleos vegetais brasileiros; $2^{\text {a }}$. ed., Ministério da Agricultura: Rio de Janeiro, 1927, p. 152.

94. Cunha, A. G.; Dicionário Histórico das Palavras Portuguesas de Origem Tupi, $4^{\mathrm{a}}$ ed., Companhia Melhoramentos: Brasília, 1998, p. 113.

95. Hoene, F. C.; Kuhlmann, M.; Handro, O.; O Jardim Botânico de São Paulo; Secretaria de Agricultura, Indústria e Comércio do Estado de São Paulo, São Paulo, 1941, p. 643.

96. Grenand, P.; Moretti, C.; Pharmacopées traditionnelles en Guyane. Créoles, Palikur, Wayãpi.; Orstom: Paris, 1987, p. 569

97. Fleury, M.; Acta Bot. Gallica 1997, 144, 473

98. Deussen, E.; Scientia Pharm. 1939, 10, 69.

99. Freise, F. W.; Süddeut. Apot-Ztg. 1937, 77, 11.

100. Rossells, B.; Simposio Internacionale Salla Medicina Indigena e Populari Dell America Latina; Roma, Itália, 1977.

101. Rodrigues,P.; Machado, G.; Simposio Internacionale Salla Medicina Indigena e Populari Dell America Latina; Roma, Itália, 1977.

102. Guillen, J. L.; Simposio Internacionale Salla Medicina Indigena e Populari Dell America Latina; Roma, Itália, 1977.

103. Cruz, G. L.; Livro Verde das Plantas Medicinais e Industriais do Brasil, Belo Horizonte, 1965, p. 394.

104. Duchesne, E. A.; Répertoire des Plantes Utiles et des Plantes Vénéneuses du Globe; J. Renouard ed.: Paris, 1836, p. 572.

105. Bertoni, M. S.; La Civilizacion Guarani, Parte III, Imprenta Y Edicion "ExSylvis"; Puerto Bertoni, 1927, p. 299.

106. Goodman, L.; Gilman, A.; As Bases Farmacológicas da Terapêutica; vol. 2, Ed. Guanabara: Rio de Janeiro, 1945, p. 1461.

107. Ferreira, M. C.; Mémoire de D. E. S. U.; Paris VI, 1992, p. 79.

108. Schultes, R. E.; Raffauf, R. F.; The Healing forest. Medicinal and toxic plants of the North West Amazonia; vol. 2; New York, 1990, p. 484.

109. Bompard, P.; Los Grandes Remedios Vegetales; Editora Caymi: Buenos Aires, 1964, p. 171.

110. Manfred, L.; Seiscientas Plantas Medicinales Argentinas y Sudamericanas; $2^{\mathrm{a}}$ ed.; Rosario, 1940, p. 503.

111. Le Cointe, P.; L'Amazonie brésilien.Le pays, ses habitants, ses ressources; vol.2; Paris, 1922, p. 493.

112. Barriga, H. G.; Flora Medicinal de Colombia. Botanica Medica; vol.3 Tercer Mundo Editores: Bogotá, 1992, p. 559.

113. Hartwell, J.L.; Lloydia 1967, 30.

114. Freise, W.; Boletim de Agricultura 1933, 34, 326

115. Matos, F. J. A.; O Formulário Fitoterápico do Professor Dias da Rocha 2a ed.; Edições UFC: Fortaleza, 1997, p. 113.

116. Fonseca, E. T.; Revista da Flora Medicinal 1939, 6, 161.

117. Teixeira, E.; Óleo de Copaíba; Imprensa Nacional: Rio de Janeiro, 1923.

118. Ferreira, M. B.; Informe Agropecuário, 1980, 61, 19.

119. Vieira, L. S.; Fitoterapia da Amazônia; $2^{\mathrm{a}}$ ed.; Editora Agronômica Ceres: São Paulo, 1992, p. 347.

120. Ribeiro, L.; Medicina no Brasil colonial; Rio de Janeiro, 1971, p. 211.

121. Figueiredo, N.; Rezadores, Pajés e Puçangas; Ed. Boitempo: Belém, 1979, p. 96.

122. Barros, M. A. G.; Brasil Florestal 1982, 12, 35

123. Mallart-Guimera, L.; Le thème de l árbre dans les contes africains; Selaf 16, Paris, 1969
124. Gildeheister, E.; Hoffman, F.; Die Atherishe Öle 1935, V, 305

125. Leite, A. C. P.; Dissertação de Mestrado; Universidade Federal do Acre, Brasil, 1997.

126. Veiga Jr., V. F.; Pinto, A. C.; Patitucci, M. L.; Quim. Nova 1997, 20, 612

127. Simonsen, R. C.; História Econômica do Brasil: 1500:1820; Metalivros: São Paulo, 1944, p. 325.

128. Arruda, F. F. A.; O Brasil Colonial; São Paulo, 1980

129. Comércio Exterior do Brasil, Instituto Brasileiro de Geografia e Estatística; 1962-1996, Rio de Janeiro, 1962-1996.

130. Gilbert, B.; Chemistry of the Amazon, Americam Chemical Society: New York, 1995, cap III.

131. Anuário Estatístico do Brasil, Instituto Brasileiro de Geografia e Estatística; Rio de Janeiro, 1996.

132. Simonetti, G.; MacDonald Encyclopedia of Herbs and Spices; MacDonald \& CO.; Verona, 1991.

133. Del Nunzio, M. J.; Aerosol Cosmet. 1985, 7, 7.

134. Del Castilho, M. I. C.; Bras. PI BR 93 01/950, 1993.

135. Del Castilho, M. I. C.; Bras. PI BR 93 02/002, 1993.

136. Wakao, Y.; Bras. PI BR 78 03/792, 1978

137. Masschelein-Kleiner, L.; Ancient binding media, varnishes and adhesives; ICCROM: Rome, 1995, p. 75.

138. Stashenko, E.; Wiame, H.; Dassy, S.; Martinez, R. J.; J. High Resol. Chromatogr. 1995, 18, 54.

139. Calvin, M.; Science 1982, 219, 24.

140. Calvin, M.; Naturwissenschaften 1980, 67, 525.

141. Calvin, M.; J. Chem. Educ. 1987, 64, 335.

142. Maugh, T.H.; Science 1979, 206, 436.

143. Sierra, G. G.; Rev. Ion 1983, 7, 141.

144. Tillotson, N. E.; U.S. pat 2.379.389, 1945.

145. Franceshini, C. A.; comunicação pessoal.

146. Imamura, P. M. Em Organic Synthesis in Brazil: A Overview, Ed. USP: São Paulo, 1992, p. 62.

147. Alencar, J. C.; Acta Amazonica 1984, 14, 255.

148. Alencar, J. C.; Acta Amazonica 1981, 11, 3

149. Oliveira, L. M. Q.; Reunião Especial da Sociedade Brasileira para o Progresso da Ciência; Cuiabá, Brasil, 1995.

150. Ramirez, N.; Arroyo, M. K.; Biotropica 1990, 22, 124.

151. Mirandola Filho, A.; Mirandola, N. S. A.; Vegetais Tintoriais do Brasil Central; Ed. Líder: Goiânia, 1991, p. 143.

152. http://www.ibiblio.org/herbmed/eclectic/kings/copaiba.html, acessada em Dezembro 2000.

153. Delle Monache, F.; Marini-Bettólo, G. B. M.; D’Albuquerque, I. L.; Delle Monache, M.; Ann. Chim. 1970, 60, 235.

154. Veiga Jr., V. F., trabalho não publicado.

155. Tschirch, A.; Keto, E.; Arch. Pharm. 1901, 548.

156. Deussen, E.; Chem. Ztg. 1912, 36, 561

157. Gottlieb, O. R.; Iachan, A.; Rev. Quim. Ind. 1945, 14, 420.

158. Braga, W.; Dissertação de Mestrado, Universidade Federal do Rio de Janeiro, Brasil, 1995

159. Morin, Ph.; Pichard, H.; Richard, H.; Caude, M.; Rosset.; J. Chromatogr. 1989, 464, 125.

160. Takeoka, G.; Flath, R. A.; Mon, T. R.; Buttery, R. G.; Teranishi, R.; Güntert, M.; Lautamo, R.; Szejtli, J.; J. High Resol. Chromatogr. 1990, 13, 202.

161. Veiga Jr., V. F.; Patitucci, M. L.; Pinto, A. C.; Zoghbi, M. G. B.; Silva, J. R. A.; Quim. Nova 1995, 18, 262.

162. Pinto, A. C.; Antunes, O. A.; Rezende, C. M.; Correia, C. R. D.; Phytochem. Anal. 1997, 8, 14

163. McCarthy, R. D.; Duthie, A. H.; J. Lip. Res. 1962, 3, 117.

164. Ramijak, Z.; Solc, A.; Arpino, P.; Schmitter, J. M.; Guiochon, G.; Anal. Chem. 1977, 49, 1222.

165. Braga, W. F.; Veiga Jr., V. F.; Patitucci, M. L.; Garrido, F. M. S.; Bergter, L.; Antunes, O. A. C.; Pinto, A. C.; J. Braz. Chem. Soc. 2000, 11, 355.

166. http://www.mre.gov.br/ndsg/textos/indama-p.htm, acessada em Dezembro 2000.

167. Veiga Jr., V. F.; Pinto, A. C.; trabalho não publicado.

168. Rezende, C. M.; Braga, W. F., Antunes, O. A. C.; Pinto, A. C., trabalho não publicado.

169. Harborne, J. B.; Baxter, H.; Phytochemical Dictionary. A Handbook of Bioactive Compounds from Plants; Taylor \& Frost: London, 1983, p. 791.

170. Merck Index; $11^{\text {th }}$ ed.

171. Duke, J. A.; Aloe Research Council, em USDA; Phytochemical Database.

172. Langenheim, J. H.; Wang, J.; Younaah Zhiwu Yanjiu 1990, 12, 85.

173. Craveiro, A. A.; Maia, J. G. S.; Varejão, M. J. C.; Filho, W. W.; Mourão, A. P.; Alencar, J. W.; Acta Amazonica 1978, 8, 705.

174. Wenninger, J. A.; Yates, R. L.; Dolinsky, M.; J. Am. Org. Anal. Chem. 1967, $50,1304$. 
175. Craveiro, A. A.; Alencar, J. W.; Machado, M. J. W.; Óleos Essenciais de Plantas do Nordeste, Ed. UFC, Fortaleza, 1981, p. 79.

176. Ferrari, M.; Pagnoni, U.M.; Pelizzoni, F.; Lukes, V.; Ferrari, G.; Phytochemistry 1971, 10, 905.

177. Delle Monache, G.; D’Albuquerque, I. L.; Delle Monache, F.; MariniBettólo, G. B. M.; Nano, G. M.; Tetrahedron Lett. 1971, 8, 659.

178. Ramaswami, S. K.; Proceedings of the 10 ${ }^{\text {th }}$. Intern. Congr. of Essencial Oils, Washington, USA, 1986, p. 951.

179. Langenheim, J. H.; Macedo, C. A.; Biochem. Syst. Ecol. 1989, 17, 207.

180. Langenheim, J. H.; Macedo, C. A.; Biochem. Syst. Ecol. 1989, 17, 551.

181. Langenheim, J. H.; Arrhenius, S. P.; Nascimento, J. C.; Biochem. Syst. Ecol. 1981, 9, 27.

182. Arrhenius, S. P.; Langenheim, J. H.; Phytochemistry 1983, 22, 471.

183. Nigan, I.; Levi, L.; J. Chromatogr. 1966, 23, 217.

184. Basile, A. C.; Sertié, J. A.; Freitas, P. C. D.; Zanini, A. C.; J. Ethnopharmacol. 1988, 22, 101.

185. Monti, H.; Tiliacos, N.; Faure, R.; Phytochemistry 1996, 42, 1653.

186. Veiga Jr., V. F.; Pinto, A. C.; trabalho não publicado.

187. Ohsaki, A.; Yan, L. T.; Ito, S.; Edatsugi, H.; Iwata, D.; Komoda, Y.; Bioorg. Med. Chem. Lett. 1994, 4, 2889.

188. Cocker, W.; Moore, A. L.; Prait, A. C.; Tetrahedron Lett. 1965, 24, 1983.

189. Delle Monache, F.; D’Albuquerque, I. L.; Corio, E.; Ann. Chim. 1969, 59, 539.

190. Spanevelo, R. A.; Vila, A. J.; Phytochemistry 1994, 35, 537.

191. Mahajan, J. R.; Ferreira, G. A. L.; Pellegrino, J.; An. Acad. Brasil. Ciências 1972, 44, 429.

192. Fernandes, R. M.; Pereira, N. A.; Paulo, L. G.; Rev. Bras. Farm. 1992, 73, 53.

193. Langenheim, J. H.; Nascimento, J. C.; Biochem. Syst. Ecol. 1986, 14, 615.

194. Ficalho, Apoth. Ztg. 1904, 86, apud Die Pflanzenstoffe, G. Fisher, J.; vol I, 1929, p. 499.

195. Mors, W. B.; Monteiro, H. J.; An. Assoc. Bras. Quím. 1959, 18, 181.

196. Buckeridge, M. S.; Rocha, D. C.; Reid, J. S. G.; Dietrich, S. M. C.; Physiol. Plant. 1992, 86, 145

197. Franco, T. T.; Rodrigues, N. R.; Serra, G. E.; Panegassi, V. R.; Buckeridge, M. S.; J. Chromatogr., B 1996, 680, 255.

198. Langenheim, J. H.; Figliuolo, R.; Naylor, S.; Wang, J.; Phytochemistry 1987, 26, 3255 .

199. Food Chemical Codex, $2^{\text {nd }}$ ed., Washington: DC, 1972, p 218.

200. Kligman, A. M.; J. Invest. Derm. 1966, 47, 393.

201. Veiga Jr., V. F.; Zunino, L.; Calixto, J. B.; Patitucci, M. L.; Pinto, A. C.; Phytot. Res. 2001, 15, 476.

202. Gilbert, B.; Mors, W. B.; Baker, P. M.; Tomassini, T. C.; Pellegrino, J.; An. Acad. Bras. Ciências 1972, 44, 423.

203. Mahajan, J. R.; Ferreira, G. A. L.; An. Acad. Brasil. Ciências 1971, 43, 611.

204. Lacey, L. A.; Schreck, C. E.; McGovern, T. P.; Mosquito News 1981, 41, 376

205. Jones, S. C.; Carter, F. L.; Mauldin, J. K.; Env. Entomol. 1983, 12, 458.

206. Lima, L. S.; Torkasky, R. M.; Psciottano, N. C.; Santos, A. M.; Schumacker, I. E.; Cosmet. Toil. 1995, 7, 39.

207. Opdyke, D. L.; Food Cosmet. Toxicol. 1976, 14, 687

208. Marussella, J. C.; Sicurella, N. A.; J. Am. Pharm. Assoc. 1960, 49, 692.

209. Abdullim, K. H.; Uchen. Zap. Kazanski Vet. 1962, 48, 75.

210. Miranda, R. C. M.; Wanderley, T. K. V.; Moura, W.; Araújo, J.; $16^{\circ}$ Simpósio de Plantas Medicinais do Brasil, Recife, Brasil, 2000.

211. Cascon, V.; Gilbert, B.; Araújo, G. L.; Rocha, L. M.; Teixeira, L. A.; Carvalho, E.S.; $16^{\circ}$ Simpósio de Plantas Medicinais do Brasil, Recife, Brasil, 2000.
212. Meyer, F.; Meyer, E.; Arzneimittel-Forsch 1959, 9, 516.

213. Lima, S. R. M.; Veiga Jr., V. F.; Pinto, A. C.; trabalho não publicado.

214. Lima, S. R. M.; Veiga Jr., V. F.; Pinto, A. C.; Henriques, M. G. M. O.; $16^{\circ}$ Simpósio de Plantas Medicinais do Brasil, Recife, Brasil, 2000.

215. Henriques, M. G. M. O.; Rosas, E. C.; Carvalho, M. V.; Veiga Jr., V. F.; Pinto, A. C.; trabalho não publicado.

216. Paiva, L. A. F.; Rao, V. S. N.; Gramosa, N. V.; Silveira, E. R.; J. Ethnopharmacol. 1998, 62, 73.

217. Brito, M. V. H.; Oliveira, R. V. B.; Morais, M. R.; Lameira, O. A.; Rev. Paraense Med. 1999, 13, 34.

218. Brito, N. M. B.; Simões, M. J.; Pessoa, A. F.; Melo, M. C. F.; Rev. Paraense Med. 1998, 12, 28.

219. Brito, N. M. B.; Simões, M. J.; Gomes, P. O.; Pessoa, A. F.; Melo, M. C. F.; Rev. Paraense Med. 1999, 13, 12.

220. Paiva, L. A. F.; Silveira, E. R.; Rao, V. S.; $16^{\circ}$ Simpósio de Plantas Medicinais do Brasil, Recife, Brasil, 2000.

221. Pinheiro, J. T.; Dissertação de Doutorado, FUP, Camarajibe, Brasil, 1993.

222. Bombonatti, P. E.; Scaranelo, R. M.; Rev. Odontol. UNESP 1996, $25,27$.

223. Costa, C. A. S.; Hebling, J.; Lia, R. C. C.; Gonzaga, H. F. S.; Vargas, P. A.; Rev. Fac. Odontol. Porto Alegre 1996, 37, 24.

224. Bandeira, M. F. C. L.; Oliveira, M. R. B.; Pizzolitto, A. C.; Benatti Neto, C.; Jorge Neto, J.; J. Bras. Clin. Estet. Odont. 1998, 3, 39.

225. Bandeira, M. F. C. L.; Oliveira, M. R. B.; Benatti Neto, C.; Lia, R. C. C.; J. Bras. Clin. Estet. Odont. 1998, 3, 42.

226. Bandeira, M. F. C. L.; Oliveira, M. R. B.; Pizzolitto, A. C.; Benatti Neto, C.; J. Bras. Clin. Estet. Odont. 1998, 3, 47.

227. Desmarchelier, C.; Coussio, J.; Ciccia, G.; Phytot. Res. 1997, 11, 460.

228. Desmarchelier, C.; Repetto, M.; Coussio, J.; Llesuy, S.; Ciccia, G.; Intern. J. Pharmacog. 1997, 35, 288.

229. Cavalcante, P. B.; Salzano, F. M.; Barros, R. M.; Ayres, M.; Bol. Mus. E. Goeldi 1970, Nova série, $36,1$.

230. Yamahara, J.; Yakugaku Zasshi 1992, 112, 645

231. Denyer, C. V.; Jackson, P.; Loakes, D. M.; Ellis, M. R.; Yound, D. A. B.; J. Nat. Prod. 1992, 57, 658.

232. Pei-Gen, X.; Nai-Gong, W.; J. Ethnopharmacol. 1991, 32, 167.

233. Zekovic, Z.; Pekie, B.; Lepojevic, Z.; Petrovic, L.; Chromatogr. 1994, 39, 587.

234. Leewenberg, A. J. M.; Medicinal and Poisonous Plants of the Tropics, Ed. Pudoc: Wageningen, 1987.

235. Kubo, I.; Muroi, H.; J. Agric. Food Chem. 1993, 41, 1102.

236. Shimizu, M.; Shogawa, H.; Matsuzawa, T.; Yonezawas, S.; Hayashi, T.; Arisawa, M.; Suzuki, S.; Yoshizaki, M.; Morita, N.; Chem. Pharm. Bull. 1990, 38, 2283.

237. Keeler, R. F.; Tu, A. T.; Toxicological of Plant and Fungal Compounds; Handbook of Natural Toxins, vol. 6, Marcel, Dekker, ed.; Nova York, 1991, p. 665.

238. Zheng, G.Q.; Kenney, P. M.; Lam, L. K. T.; J. Nat. Prod. 1992, 55, 999.

239. Kang, R.; Helms, R.; Stout, M. J.; Jaber, H.; Nakatsu, T.; J. Agric. Food Chem. 1992, 40, 2328

240. Jacobson, M.; Glossary of Plant-Derived Insect Deterrents; CRC Press: Boca Raton, 1990, p. 213.

241. Tanaka, S., Akimoto, M., Tambe, Y., Tabata, M.; Phytot. Res. 1996, 10, 238

242. Bettarini, F.; Borgonovi, G. E.; Insect Sci. Applic. 1991, 14, 93.

243. Alves, T. M. A.; Chaves, P. P. G.; Santos, L. M. S. T.; Nagem, T. J.; Murta S. M. F.; Ceravolo, I. P.; Romanha, A. J.; Zani, C. L.; Planta Med. 1995, 61,85 .

244. Cunha, K. M. A.; Silveira, E. R.; Rao, V. S.; $16^{\circ}$ Simpósio de Plantas Medicinais do Brasil, Recife, Brasil, 2000. 